\title{
THE MATERIAL EVIDENCE OF THE ROMAN CULT OF MITHRAS IN DACIA
}

\author{
CIMRM SUPPLEMENT OF THE PROVINCE
}

\begin{abstract}
Summary: Since M. J. Vermaseren's visit to Romania and the publication of the second volume of his monumental corpus on Mithraic finds in 1960, the once-called "Mithraic Studies" has had numerous paradigmatic shifts and changed its major focus points. Besides the important changes in the theoretical background of the research, the archaeological material regarding the Mithraic finds of Dacia - one of the richest provinces in this kind of material - has also been enriched. Several new corpora focusing on the Mithraic finds of Dacia were published in the last decade. This article will present the latest currents in the study of the Roman cult of Mithras and will give an updated list of finds and several clarifications to the latest catalogue of Mithraic finds from the province.
\end{abstract}

Key words: Dacia, cult of Mithras, CIMRM Supplement, lived ancient religion, archaeology of religion

Maarten J. Vermaseren, the leading scholar of what was once called "Mithraic Studies and Oriental Religions", who revolutionized the study of Roman religion by establishing the EPRO series in the 1950's - 70's, ${ }^{1}$ visited Romania in 1958. ${ }^{2}$ As he remarked in the introduction of the second volume of CIMRM [Corpus Inscriptionum et Monumentorum Religionis Mithriacae] in 1960, during his stay in the Communist Romania in 1958, he was accompanied by Constantin Daicoviciu and Emil Condurachi, the two leading figures of Altertumwissenschaft in Romania. ${ }^{3}$ While the first presented

${ }^{1}$ GORDON, R.: Cosmology, Astrology and Magic: Discourse, Schemes, Power and Literacy. In BRICAUlt, L. - BonNet, C. (eds): Panthée: Religious Transformations in the Graeco-Roman Empire. Leiden 2013, 89-90, esp. nn. 25-27.

${ }^{2}$ Almost all of the authors and editors of the great corpora (CIL, MMM, CIMRM) personally visited Transylvania and, later, Romania. While the visit of Th. Mommsen and F. V. Cumont were analyzed in a few articles in the last decades, the scholarly relations of M. J. Vermaseren with the Romanian scholars and his visit to Romania is still unstudied.

${ }^{3}$ Vermaseren, M. J: Corpus Inscriptionum et Monumentorum Religionis Mithriacae. Vol. I-II. The Hague 1956-1960, vi. About ancient studies and Communism of that period, see MATEI-POPESCU, F.: 
to Vermaseren the finds from Transylvania, Condurachi was responsible for the finds from Oltenia and, probably, Dobrudja. From his short remarks mentioned in the entries on Dacia, Vermaseren consulted personally the archaeological collections of Cluj, Alba Iulia and Sibiu, although his itinerary in the country was yet unsure. He had at his disposal the original publication of Pál Király on the Mithraeum from Sarmizegetusa, translated for him by the French Orientalist, H. Boissin. ${ }^{4}$ From his notes in the CIMRM II, we can deduce that he met Dumitru Tudor and Dan Popescu too. ${ }^{5}$

Since the publication of his monumental corpus, the study of the Roman cult of Mithras has changed radically, while the archaeological data from Dacia has increased significantly. Both changes urged this scholarship to reconsider the heritage of Vermaseren and to find new paths for future researches.

\section{NEW PERSPECTIVES IN THE STUDY OF THE ROMAN CULT OF MITHRAS}

In the last decade the study of the cult of Roman Mithras has changed radically. From the influential doctrine of Cumont, who presented the cult as an "Iranian" and "Persian" cult diffused by prophets from the East to the West, ${ }^{6}$ to the Oriental, soteriological and mystery religions, ${ }^{7}$ and highly archaeological perspectives of Vermaseren, these cults are known today as elective cults or small group religions. ${ }^{8}$ From the obsessive quest for the origins and founders of the cult, and after developing the abundant iconographic typologies, recent research is trying to understand the Roman cult of Mithras ${ }^{9}$ as

Imaginea Daciei Romane în istoriografia romănească între 1945 şi 1960 [The Image of Roman Dacia in Romanian Historiography between 1945-1960]. SCIVA 58 (2007) 265-288; SzABÓ, CS.: Roman Religious Studies in Romania. Historiography and New Perspectives. In Ephemeris Napocensis 24 (2014) 195-208.

${ }^{4}$ It is strange why he did not ask for the older Hungarian bibliography of András Bodor, fluent in English and Oxford alumnus, well known friend of Constantin Daicoviciu and the only Hungarian scholar of antiquity based in Cluj in that period. See also: SzABÓ, CS.: Bodor András, az ókortudós [B. A. the Classical Scholar]. In RÜSZ-FOGARASI, E. (ed.): Erdélyi fürdökultúra. A Kolozsvári Magyar Történeti Intézet Évkönyve. Kolozsvár 2016, 219-227.

${ }^{5}$ Due to his visit in Alba Iulia he surely met Ion Berciu, who later contributed with Constantin C. Petolescu to the EPRO series.

${ }^{6}$ Gordon, R. L.: Franz Cumont and the Doctrines of Mithraism. Journal of Mithraic Studies 1 (1975) 215-248; BECK, R.: Mithraism since Franz Cumont. In ANRW II.17.4 (1984) 2002-2115; BONNET, C.: The Religious Life in Hellenistic Phoenicia: Middle Ground and New Agencies. In RÜPKE, J. (ed.): The Individual in the Religions of the Ancient Mediterranean. Oxford 2013, 41-58.

${ }^{7}$ On the new perspectives on mystery religions, see BREMMER, J.: Initiation into the Mysteries of the Ancient World. Berlin-Boston 2014.

${ }^{8}$ BONNET, C. - SCARPI, P. - RÜPKE, J. (eds): Religions orientales - culti misterici: Neue Perspektiven, nouvelles perspectives, prospettive nuove. Im Rahmen des trilateralen Projektes „Les religions orientales dans le monde gréco-romain “. Stuttgart 2006; GORDON, L. R.: Institutionalised Religious Options: Mithraism. In RÜPKE, J. (ed.): The Companion of Roman Religion. Malden, MA - Oxford 2007, 39-405; Versluys, M. J.: Orientalising Roman Gods. In BRICAUlT, L. - BonNET, C. (ed.): Panthée: Religious Transformations in the Graeco-Roman Empire. Leiden 2013, 239-259; GORDON, L. R.: Persae in spelaeis solem colunt: Mithra(s) between Persia and Rome. In StrootmanN, R. - VersluYs, M. J. (eds): Persianism in Antiquity. Stuttgart 2017, 289-327.

9 The very notion of "Roman cult of Mithras" suggests a sharp delimitation and contrast with the pre-Roman forms of the cult: BECK (n. 6), GORDON 2007 (n. 8); BRICAULT-BONNET (n. 8). 
a form of religious communication with superhuman divine agency, where competition, religious experience, material agency, embodiment and local appropriations play a key role in the analysis. 10

The cult should not be necessarily interpreted as a religion founded by a single prophet, ${ }^{11}$ having one single doctrinal narrative and a typological iconography diffused from a central group and place in the Empire, in a temporary linear and spatial line. Instead, it should be seen as a religious bricolage and intraconnectivity ${ }^{12}$ of Hellenistic entrepreneurs influenced, shaped, and constantly appropriated by Orphism, ${ }^{13}$ Zoroastrianism, ${ }^{14}$ Manicheism, ${ }^{15}$ and other religious ideas and groups of the Roman Empire in the $1 \mathrm{st}-4$ th centuries. ${ }^{16}$ Studies focusing on the formation, diffusion, and maintaining strategies of contemporary small group religions also help us to understand the possible mechanisms of ancient small group religions. ${ }^{17}$ Studies focusing on the mobility of Mithras-worshippers and the relationship with the other cults and forms of religious communication help also to understand the complexity of ancient Mediterranean religions, where the dichotomy between "Roman, public and official" cults and "exotic, new and Oriental" religions was not that strong as once Vermaseren or Cumont stated. ${ }^{18}$

Although the literary sources on the cult of Mithras has not increased significantly since F. Cumont's collection, ${ }^{19}$ the archaeological material has changed radically since M. Vermaseren's corpus. The discovery of numerous important sanctu-

\footnotetext{
${ }^{10}$ For the application of the Lived Ancient Religion approach on the cult of Mithras, see: DIRVEN, L.: The Mithraeum as tableau vivant. A Preliminary Study of Ritual Performance and Emotional Involvement in Ancient Mystery Cults. Religion in the Roman Empire 1 (2015) 20-50. For the major changes in Roman religious studies, see SzABÓ CS.: Párbeszéd Róma isteneivel. A római vallások kutatásának jelenlegi állása és perspektívái [In Dialogue with the Gods: Current State and New Perspectives of Roman Religious Studies]. Orpheus Noster 9 (2017) 151-163.

${ }^{11}$ The idea of S. Wikander, diffused by R. Merkelbach and especially I. Tóth. See TóTH, I.: Pannóniai vallástörténet [History of Religion in Pannonia]. Pécs-Budapest, 2015.

${ }^{12}$ On the notion of intraconnectivity, see BUSCH, A. - VERSLUYS, M.: Indigenous Pasts and the Roman Present. In Busch, A. - VERSLuYs, M. (eds): Reinventing the 'Invention of Tradition'. Indigenous Pasts and the Roman Present [Morphomata 32]. Köln 2015, 7-18.

${ }^{13}$ JÁuregui, M. H.: Orphism and Christianity in Late Antiquity. Berlin - New York 2010, 72; BREMMER (n. 7) 119.

${ }^{14}$ GORDON 2017 (n. 8).

${ }^{15}$ NAGY, L.: The Short History of Time in the Mysteries of Mithras: The Order of Chaos, the City of Darkness, and the Iconography of Beginnings. Pantheon 7 (2012) 37-58.

${ }^{16}$ NeMETI, S.: Recent Reflections on the Cult of Mithras. In NEMETI, S. - SzABÓ, CS. - BodA, I. (eds): Si deus si dea. New Perspectives in the Research of Roman Religion in Dacia [Studia Universitatis Babes Bolyai, vol. 61, no. 1]. 2016, 74-81.

${ }^{17}$ BECK, R.: The Mysteries of Mithras. In KloppenBorg, J. - Wilson, G. (eds): Voluntary Associations in the Ancient World. London 1996, 176-185; REMUS, H.: Aelius Aristides at the Asclepeion in Pergamum. In KLOPPENBORG-WILSON 146-175.

${ }_{18}^{18}$ RÜPKE, J.: Pantheon. Geschichte der antiken Religionen. Stuttgart 2016, 322-326.

${ }^{19}$ LÁSZLÓ, L. - NAGY, L. - SzABÓ, Á.: Mithras misztériumai I-II [Mysteries of Mithras]. Budapest, 2005 is probably the latest and most complete selection of literary passages, unfortunately available only in Hungarian. See also: http://www.tertullian.org/rpearse/mithras/literary_sources.htm. Last accessed 01.02.2017.
} 
aries, ${ }^{20}$ the more intense focus on Mithraic small finds ${ }^{21}$ and the changes in the general approaches of archaeology of religion, ${ }^{22}$ have urged the necessity for a reinterpretation of the material evidence of the cult. Although there was an intention to publish a new CIMRM Supplement for all the provinces, ${ }^{23}$ the initiative never happened. ${ }^{24}$ Several volumes were published, however, with the new finds in particular sites ${ }^{25}$ or provinces. $^{26}$ The archaeological material published by M. Vermaseren needs not only a critical reconsideration, but also a supplement for each province. Archaeology of religion is recently focusing on several new aspects of the Mithras cult, analyzing the inner structure and the functionality of the mithraea, mithraea as sacred landscapes, ${ }^{27}$ the use and role of small finds, and even some cognitive aspects of the sanctuary and the material agency used in the religious communication. ${ }^{28}$

In Romanian scholarship, after the publication of the CIMRM II, several studies focussed on and published individual pieces and new finds, local iconographies and, recently, social aspects of the worshippers. ${ }^{29}$ Three corpora have also been established since then: the unpublished PhD of M. Pintilie, ${ }^{30}$ the PhD thesis of J. R. C.

${ }^{20}$ Based on my own list and John W. Brandt's contribution, Roger Pearse established the following list of discoveries since 1960: http://www.tertullian.org/rpearse/mithras/display.php?page=Discoveries since_1960. Last accessed 01.02.2017.

${ }^{21}$ Martens, M. - De BoE, G. (eds): Roman Mithraism: The Evidence of the Small Finds. Papers of the International Conference, Tienen, 7-8 November 2001. Amsterdam 2004; FRACKOWIAK, D.: Mithras ist mein Kranz. Weihegrade und Initiationsrituale im Mithraskult. In Imperium der Götter: Isis Mithras - Christus. Kulte und Religionen im Römischen Reich. Karlsruhe 2013, 230-237; SzABÓ, CS.: Notes on the Mithraic Small Finds from Sarmizegetusa. Ziridava 28 (2014) 135-148.

${ }^{22}$ RAJA, R. - RÜPKE, J.: Archaeology of Religion, Material Religion and the Ancient World. In RAJA, R. - RÜPKE, J. (eds): A Companion to the Archaeology of Religion in the Ancient World. Leiden-Boston 2015, 1-27.

${ }^{23}$ http://www.tertullian.org/rpearse/mithras/display.php?page $=$ cimrm_supplement. Last accessed 01.02.2017.

${ }^{24}$ Another attempt by C. Witchel also failed. Two proposals by N. Belayche and C. Witchel (with the co-operation of many scholars from Europe and America) and one by A. Mastrocinque concerning Italy were not funded. Oral confirmation of D. Frackowiak from Heidelberg. For a less systemathic attempt see also the project of O. Harl: Ubi Erat Lupa and a digitized catalogue of the LIMC.

${ }^{25}$ Huld-ZeTsche, I.: Der Mithraskult in Mainz und das Mithräum am Ballplatz. Mainz 2008; Martens, M.: Life and Culture in the Roman Small Town of Tienen. Transformations of Cultural Behaviour by Comparative Analysis of Material Culture Assemblages. PhD thesis, Amsterdam 2012 (unpublished). Open access.

${ }^{26}$ For the Danubian provinces, see FEILER J.: Mithras-emlékek Magyarországon. BA thesis, ELTE, Budapest 1994 (manuscript); SELEM, P. - BRČIĆ, I.: Religionum Orientalum monumenta et inscriptiones ex Croatia [ROMIC] I. [Znakovi I Riječi Signa et Litterae vol. V]. Zagreb 2015.

${ }^{27}$ KLÖCKNER, A.: Die 'Casa del Mitra' bei Igabrum und ihre Skulpturenausstattung. In VAQUERIZO, D. (ed.): Las áreas suburbanas en la ciudad histórica: topografía, usos, function. Cordóba 2010, 255-265; SzABÓ, Á.: A mithraeumok tájolásának kérdéséhez [On the Orientation of the Mithraea]. Antik Tanulmányok 56 (2012) 125-134; NiELSEN, I.: Housing the Chosen: The Architectural Context of Mystery Groups and Religious Associations in the Ancient World. Turnhout 2014.

${ }^{28}$ MARTIn, L.: The Mind of Mithraists: Historical and Cognitive Studies in the Roman Cult of Mithras. London 2014.

${ }^{29}$ BODA, I. - SzABÓ, CS.: The Bibliography of Roman Religion in Dacia. Cluj-Napoca 2014, 110-115.

${ }^{30}$ PINTILIE, M.: Mithraea în Dacia. Ephemeris Napocensis 9-10 (1999-2000) 231-243; PINTILIE, M.: Mithraea în Dacia. PhD thesis, University of Babes-Bolyai, Cluj-Napoca 2002 (unpublished). Her work can be consulted only in the Central Library of the Babes-Bolyai University, which is not under 
Garcia $^{31}$ and the PhD thesis of G. Sicoe - the latter considered at the moment the latest and best catalogue of Mithraic finds from Dacia. ${ }^{32}$ Although many of the new finds since 1960 were included in these three new catalogues and some of the inscriptions attributed wrongly by Vermaseren to the cult were excluded, several clarifications and new finds need to be added to these.

In the following contribution, I will present a corrected and updated list of the major corpora, highlighting some clarifications and presenting the new finds too.

\section{CIMRM DACIAE: SUPPLEMENTUM ET CORRIGENDUM}

\begin{tabular}{|c|c|c|c|}
\hline CIMRM & $\begin{array}{l}\text { CARBÓ-GARCIA } \\
\text { (n. 31) }\end{array}$ & SICOE (n. 32) & NEW FINDS OR COMMENTS \\
\hline 1916 & $\begin{array}{l}\text { Cat. no. } 334 \text {. } \\
\text { Enrolls it among uncer- } \\
\text { tain inscriptions }\end{array}$ & $\begin{array}{l}\text { Does not accept it as a } \\
\text { Mithraic inscription. }\end{array}$ & \\
\hline 1917 & Cat. no. 41. & Cat. no. 1. & $\begin{array}{l}\text { The altar was discovered in the founda- } \\
\text { tion of the Tivoli House next to the } \\
\text { Bánffy Palace in } 1898 \text { during the con- } \\
\text { struction of the Status-palace. It could } \\
\text { mark a possible location of a mithraeum } \\
\text { in Napoca }\end{array}$ \\
\hline
\end{tabular}

the open access yet. The work contributed with the new data especially regarding the topography of the finds and the possible list of sanctuaries, but mostly used the material published by M. Vermaseren and later, by I. Berciu and C. C. Petolescu.

${ }^{31}$ CARBÓ GARCIA, J. R.: Los cultos orientales en la Dacia romana. Formas de difusión, integración y control social e ideológico. Salamanca 2010, 113-181 and 717-805. His work opened new questions regarding the possible differentiation of Mithras and Sol Invictus, although his selection is not always plausible. His work is less known in the Western literature and was rarely cited till 2014, when his book was replaced by Sicoe's catalogue.

${ }^{32}$ SiCOE, G.: Die mithräischen Steindenkmäler aus Dakien. Cluj-Napoca 2014. For a review and a few critical notes, cf. http://bmcr.brynmawr.edu/2014/2014-10-56.html, last accessed: 1.02.2017. In establishing and analysing the local iconographic features, he omits to analyze the dynamics of iconographic languages on an Empire scale. He does not cite either the $L I M C$, nor the latest works on Mithraic visual languages (I. Elsner for example). It is important to mention that the majority of the archaeological material presented in his volume have undocumented proveniences and that few of the pieces were examined petrographically, which could help more in the identification of workshops. Similarly, his book does not analyze the social aspects of the Mithraic groups, the dynamics between these groups in urban, rural and provincial contexts and the lived aspects of religious communication. A detailed examination of the museum archives and deposits in Romania (especially Oltenia) is necessary to establish a complete list of Mithraic finds from Dacia.

${ }^{33}$ There are no direct proofs for the existence of a mithraeum, but the altar found in the foundation of the Tivoli House could indicate the presence of a sanctuary. Opreanu presumed a sanctuary of Mithras outside of the city wall, at the Str. Crisan no. 21: OPREANU, C. H.: Recently Discovered Marble Statuette of Nemesis at Napoca. In GAGGADIS-RoBIN, V. (ed.): Les ateliers de sculpture régionaux: techniques, styles et iconographie. Actes du $X^{e}$ colloque international sur l'art provincial romain, Arles et Aix-enProvence, 21-23 mai 2007. Arles 2009, 721-725. 


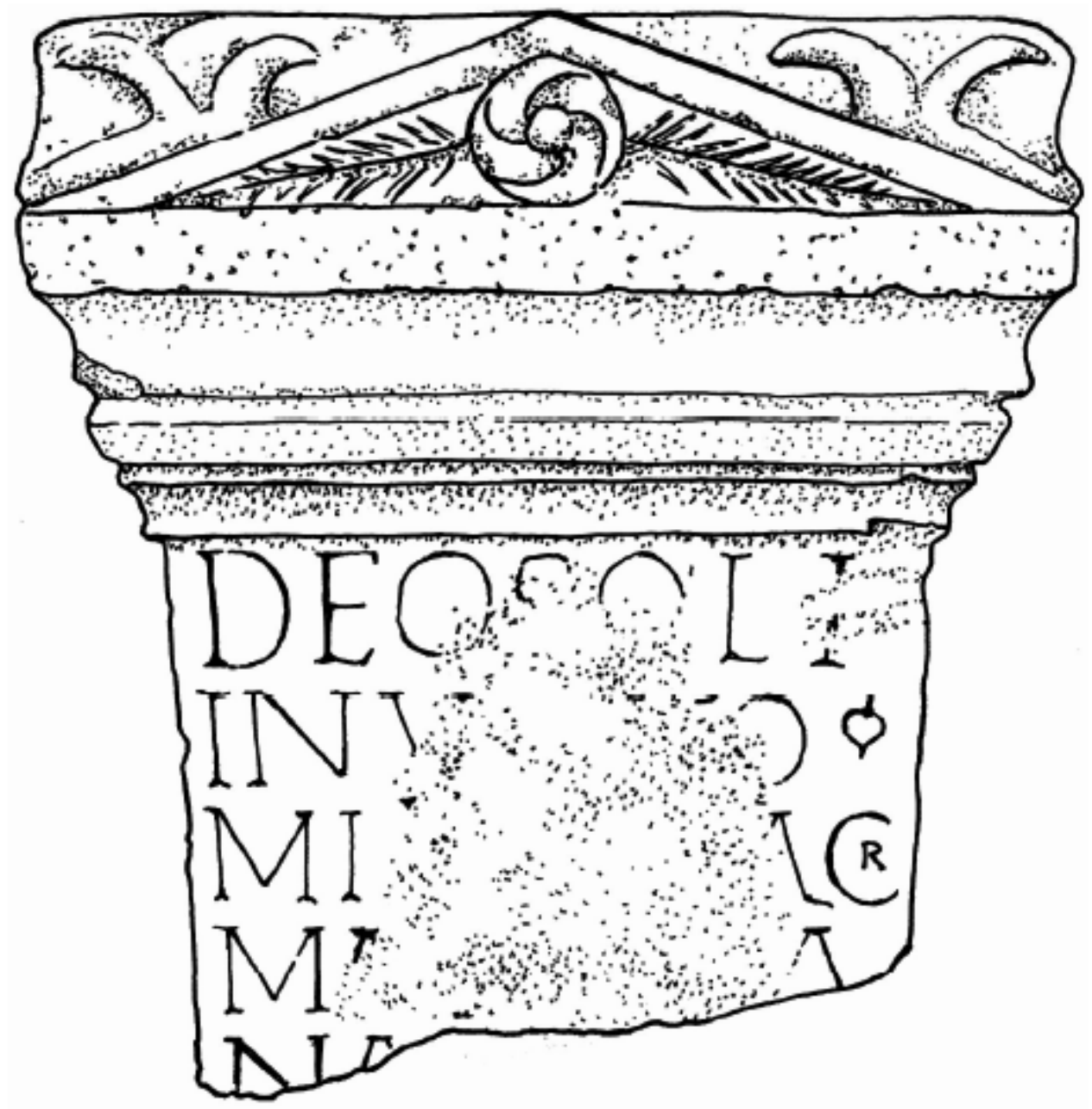

Fig. 1. Possible Mithraic altar from Napoca (after OpREANU [n. 33] fig. 2)

\begin{tabular}{|l|l|l|}
\hline & Cat. no. 2. & $\begin{array}{l}\text { Uncertain. The fragmentarily preserved } \\
\text { dedication could belong to different gods } \\
\text { (Hercules, Sol Invictus) }\end{array}$ \\
\hline & $\begin{array}{l}A E \text { 2010, 1369= OPREANU 2009 (n. 33). } \\
\text { The fragmentarily preserved inscription } \\
\text { was found in Cluj-Napoca, at the foun- } \\
\text { dation of a house at Crisan Str. 21. ap- } \\
\text { prox. 2 km from the Northern edge of } \\
\text { the Roman city. The Mithraic nature } \\
\text { of the inscription is uncertain. (fig. 1) }\end{array}$ \\
\hline
\end{tabular}




\section{GHERLA}

\begin{tabular}{|c|c|c|c|}
\hline CIMRM & $\begin{array}{c}\text { CARBÓ-GARCIA } \\
\text { (n. 31) }\end{array}$ & SICOE (n. 32) & NEW FINDS OR COMMENTS \\
\hline 1918 & $\begin{array}{c}\text { Cat. no. 35. } \\
\text { Accepts the reading of od } \\
\text { Vermaseren and Cumont } \\
\text { and argues that the } \\
\text { Ala II Pannoniorum } \\
\text { stationed in Gherla. }\end{array}$ & $\begin{array}{l}\text { Does not accept it as } \\
\text { a Mithraic inscription, } \\
\text { citing } A E \text { 1960, 222. }\end{array}$ & \\
\hline
\end{tabular}

\section{DOMNEȘTI}

\begin{tabular}{|c|c|c|l|}
\hline CIMRM & $\begin{array}{c}\text { CARBÓ-GARCIA } \\
\text { (n. 31) }\end{array}$ & \multicolumn{1}{|c|}{ SICOE (n. 32) } & \multicolumn{1}{c|}{ NEW FINDS OR COMMENTS } \\
\hline N. & & $\begin{array}{c}\text { Cat. no. 15. } \\
\text { Reads the inscription as } \\
\text { one dedicated to IOM } \\
\text { and Mithras. }\end{array}$ & $\begin{array}{l}\text { The Mithraic nature of the inscription is } \\
\text { uncertain, although Publius Aelius Ma- } \\
\text { r(i)us certainly plays an important role } \\
\text { in the formation of Mithraic groups in } \\
\text { Dacia. See SzABÓ, CS.: The Cult of } \\
\text { Mithras in Apulum: Communities and } \\
\text { Individuals. In ZERBINI, L. (ed.): Culti } \\
\text { e religiositá nelle province danubiane. } \\
\text { Bologna 2015, 414, n. 76. }\end{array}$ \\
\hline
\end{tabular}

\section{DRAGU $^{34}$}

\begin{tabular}{|c|l|c|c|}
\hline CIMRM & \multicolumn{1}{|c|}{$\begin{array}{c}\text { CARBÓ-GARCIA } \\
\text { (n. 31) }\end{array}$} & SICOE (n. 32) & \multicolumn{1}{|c|}{ NEW FINDS OR COMMENTS } \\
\hline 1919 & $\begin{array}{l}\text { As an anepigraphic } \\
\text { monument, it is not in- } \\
\text { cluded in his epigraphic } \\
\text { list. }\end{array}$ & Cat. no. 3. abb. 23. & $\begin{array}{l}\text { See also: SZABÓ, Cs.: Searching for the } \\
\text { Lightbearer: Notes on a Mithraic Relief } \\
\text { from Dragu. Marisia 23 (2012) 135- } \\
145 .\end{array}$ \\
\hline
\end{tabular}

${ }^{34}$ Few other Roman finds were discovered in this area, which could indicate a Roman settlement or villa. It is uncertain if the middle-sized ex voto belonged to a sanctuary or was part of a private worship. 


\section{POTAISSA $^{35}$}

\begin{tabular}{|c|c|c|c|}
\hline CIMRM & $\begin{array}{c}\text { CARBÓ-GARCIA } \\
\text { (n. 31) }\end{array}$ & SiCOE (n. 32) & NEW FINDS OR COMMENTS \\
\hline $1920-21$ & Cat. no. 47. & Cat. no. 4. abb. 91. & \\
\hline $1922-23$ & Cat. no. 48. & Cat. no. 8. & \\
\hline $1924-25$ & Cat. no. 49. & Cat. no. 6. abb. 35 . & \\
\hline 1926 & & Cat. no. 7. abb. 85 . & \\
\hline 1927 & Cat. no. 50 . & Cat. no. 11. & \\
\hline 1928 & Cat. no. 51. & Cat. no. 9. & \\
\hline 1929 & \begin{tabular}{|l|}
\multicolumn{1}{c|}{ Cat. no. 336.} \\
Lists among uncertain \\
inscriptions.
\end{tabular} & Cat. no. 12 . & \\
\hline \multirow[t]{4}{*}{2377} & Cat. no. 52 . & Cat. no. 10. & \\
\hline & & Cat. no. 13 . & $\begin{array}{l}\text { The inscription has been read differently. } \\
\text { The latest interpretation (ILD 492) does } \\
\text { not accept it as a Mithraic one. }\end{array}$ \\
\hline & & Cat. no. 252. abb. 19. & $\begin{array}{l}\text { Colossal head of Mithras: a large sized } \\
\text { head of a young, bearded figure was at- } \\
\text { tributed to Mithras. See also BĂRBU- } \\
\text { LESCU, M.: Arta romană din Potaissa } \\
\text { Cluj-Napoca } 2015,40 \text {, cat. no. } 1 \text {. }\end{array}$ \\
\hline & & Cat. no. 253 . & \\
\hline
\end{tabular}

CEANU Mic ${ }^{36}$

\begin{tabular}{|c|c|c|c|}
\hline CIMRM & $\begin{array}{c}\text { CARBÓ-GARCIA } \\
\text { (n. 31) }\end{array}$ & SICOE (n. 32) & NEW FINDS OR COMMENTS \\
\hline 2376 & $\begin{array}{l}\text { Cat. no. 331. } \\
\text { Enrolls it among the } \\
\text { uncertain inscriptions, } \\
\text { probably to Sol. }\end{array}$ & Cat. no. 14. & \\
\hline
\end{tabular}

${ }^{35}$ Although a mithraeum was not identified archaeologically or epigraphically in Potaissa, the existence of a sanctuary seems to be very plausible. Some of the finds are concentrated in the same, SE area of the fort. A statue of a genius, identified once as a Mithraic iconography is not plausible, the large sized head could be also more a genius legionis. In contrast with the other legionary centre, Apulum, the material evidence of a Mithras cult is insignificant in Potaissa. This could be explained with the dominant presence of Isiac cults or with Medieval looting. It is also possible that on one of the slopes of the city there is still an intact mithraeum.

${ }^{36}$ A possible Roman settlement was identified there in the beginning of the 20th century. The Mithraic altar could belong also to Potaissa. 


\section{DeCEA Mureșului ${ }^{37}$}

\begin{tabular}{|c|c|c|l|}
\hline CIMRM & $\begin{array}{c}\text { CARBÓ-GARCIA } \\
\text { (n. 31) }\end{array}$ & SICOE (n. 32) & \multicolumn{1}{|c|}{ NEW FINDS OR COMMENTS } \\
\hline 1930 & Not presented. & Cat. no. 59. abb. 8. & $\begin{array}{l}\text { The name of the locality and the de- } \\
\text { tailed journal of Károly Herepei was } \\
\text { not known by Vermaseren. }\end{array}$ \\
\hline 1931 & Cat. no. 60. & Cat. no. 60. & Identical with CIMRM 1933. \\
\hline 1932 & Cat. no. 61. & Cat. no. 61. & \\
\hline 1933 & Cat. no. 60. & Cat. no. 60. & Identical with CIMRM 1931. \\
\hline
\end{tabular}

APULUM $^{38}$

\begin{tabular}{|c|c|c|l|}
\hline CIMRM & $\begin{array}{c}\text { CARBÓ-GARCIA } \\
\text { (n. 31) }\end{array}$ & SICOE (n. 32) & \multicolumn{1}{c|}{ NEW FINDS OR COMMENTS } \\
\hline 1937 & Cat. no. 2. & Cat. no. 20. & $\begin{array}{l}\text { SZABÓ, CS.: The Mithraic Statue of Se- } \\
\text { cundinus from Apulum. ReDiva 1 (2013) } \\
\text { 45-65. Probably part of the so called } \\
\text { Kaftal Mithraeum. }\end{array}$ \\
\hline 1938 & $\begin{array}{l}\text { As an anepigraphic } \\
\text { monument, it is not in- } \\
\text { cluded in his epigraphic } \\
\text { list. }\end{array}$ & Cat. no. 18 & $\begin{array}{l}\text { Identical with CIMRM 1986. See SzABÓ, } \\
\text { Cs. - BounEGRU, G. - SAVA, V.: Mith- } \\
\text { ras Rediscovered. Notes on the CIMRM } \\
\text { 1938. Ziridava 28 (2014) 149-156 } \\
\text { fig. 2) }\end{array}$ \\
\hline 1939 & Cat. no. 3. & Cat. no. 23. & $\begin{array}{l}\text { Probably discovered during the build- } \\
\text { ing of the railway in the Northern half } \\
\text { of the Colonia Aurelia Apulensis }\end{array}$ \\
\hline 1940 & Cat. no. 4. & Cat. no. 24. & $\begin{array}{l}\text { The reading of Vermaseren was not ac- } \\
\text { cepted later by I. Piso. The suggestion } \\
\text { of Sonoc-Munteanu is not plausible: } \\
\text { SonOC, A. - MunTEANU, C.: Observa- } \\
\text { tii privind câteva monumente mithraice } \\
\text { din Sudul Transilvaniei. Acta Musei } \\
\text { Brukenthal 3.1 (2008) 156-157. }\end{array}$ \\
\hline 1941 & Cat. no. 5. & Cat. no. 25. & \\
\hline
\end{tabular}

${ }^{37}$ The discovery of the small Mithraeum of Decea Muresului was described by Károly Herepei in 1888 and later published by M. Takács in 1987. See also: PINTILIE 1999-2000 (n. 30.).

${ }^{38}$ Vermaseren presented the finds in two major groups: Maros-Porto (Partos today), which was the territory of the Colonia Aurelia Apulensis and the canabae, later Municipium Septimium Apulense. He mentioned, wrongly, that the Maros-Porto was the canabae originally. In the conurbation there is only one mithraeum excavated systematically. Based on the history of the research and the presumed topography of the finds, at least 6-7 sanctuaries could exist in the two cities. 


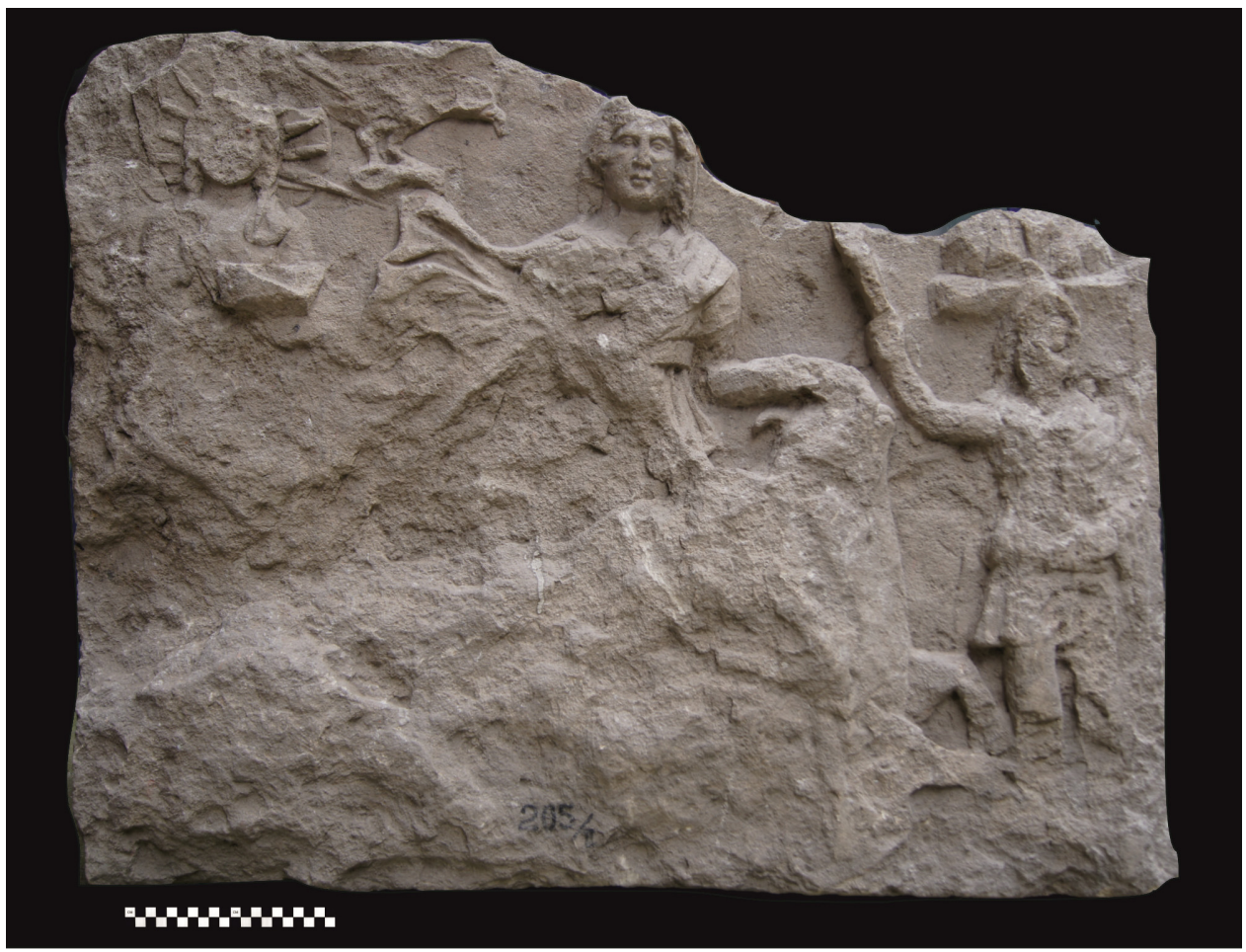

Fig. 2. Large sized Mithras relief from Apulum (after SZABÓ-BounEGRU-SAVA 2014)

\begin{tabular}{|c|c|c|c|}
\hline $1942-43$ & Cat. no. 6. & Cat. no. 21. & $\begin{array}{l}\text { Probably part of the so called Mith- } \\
\text { raeum of Károly Pap. See SzABÓ, CS. - } \\
\text { BODA, I. - TIMOC, C.: Notes on a New } \\
\text { Mithraic Inscription from Dacia. In AR- } \\
\text { DEVAN, R. - BEU-DACHIN, E. (eds): } \\
\text { Mensa Rotunda Epigraphica Napocen- } \\
\text { sis. Cluj-Napoca 2016, 91-105. }\end{array}$ \\
\hline $1944-45$ & Cat. no. 7. & Cat. no. 26. & $\begin{array}{l}\text { Probably part of the so-called Mith- } \\
\text { raeum of Károly Pap. See SzABÓ, CS. - } \\
\text { BODA, I. - TIMOC, C.: Notes on a New } \\
\text { Mithraic Inscription from Dacia. In AR- } \\
\text { DEVAN, R. - BEU-DACHIN, E. (eds): } \\
\text { Mensa Rotunda Epigraphica Napocen- } \\
\text { sis. Cluj-Napoca 2016, 91-105. }\end{array}$ \\
\hline 1946 & $\begin{array}{l}\text { Cat. no. } 319 \text {. } \\
\text { Lists among the uncer- } \\
\text { tain dedications. }\end{array}$ & $\begin{array}{l}\text { Did not accept it as } \\
\text { Mithraic. SICOE (n. } 32) \\
28, \text { n. } 96 .\end{array}$ & $\begin{array}{l}\text { Was found in the vicinity of the Forum } \\
\text { and the major sanctuary area of the } \\
\text { Colonia Aurelia Apulensis. Probably } \\
\text { not related to a mithraeum. See Digital } \\
\text { Map of Apulum [DMA] (https://religio } \\
\text { academici.wordpress.com/dma/) }\end{array}$ \\
\hline $1947-48$ & Cat. no. 8. & Cat. no. 16. & $\begin{array}{l}\text { SZABÓ, CS.: The Mithraic Statue of Se- } \\
\text { cundinus from Apulum. ReDiva } 1 \text { (2013) } \\
\text { 45-65. }\end{array}$ \\
\hline
\end{tabular}




\begin{tabular}{|c|c|c|c|}
\hline 1949 & $\begin{array}{l}\text { As an anepigraphic } \\
\text { monument, it is not in- } \\
\text { cluded in his epigraphic } \\
\text { list. } \\
\end{array}$ & Cat. no. 19. abb. 3 . & \\
\hline 1950 & Cat. no. 9. & Cat. no. 51. & \\
\hline 1951 & Cat. no. 10 . & Cat. no. 52 . & $\begin{array}{l}\text { The inscription could be an unfinished } \\
\text { one, referring to the building of a mith- } \\
\text { raeum or a rare case of a supernomina. }\end{array}$ \\
\hline 1952 & $\begin{array}{l}\text { Cat. no. } 318 \text {. } \\
\text { List among the uncer- } \\
\text { tain dedications, possi- } \\
\text { bly to Sol. }\end{array}$ & $\begin{array}{l}\text { Did not accept it as } \\
\text { Mithraic. SICOE (n. 32) } \\
\text { 28, n. } 96 .\end{array}$ & \\
\hline 1953 & & & $\begin{array}{l}\text { Mithraeum of Oancea. For a possible lo- } \\
\text { cation, see } D M A \text {. }\end{array}$ \\
\hline 1954-55 & Cat. no. 11 . & Cat. no. 29. & \\
\hline 1956 & $\begin{array}{l}\text { As an anepigraphic } \\
\text { monument, it is not in- } \\
\text { cluded in his epigraphic } \\
\text { list. }\end{array}$ & Cat. no. 32. abb. 17. & $\begin{array}{l}\text { See also SzABÓ, CS.: Notes on a New } \\
\text { Cautes Statue from Apulum. Archaeo- } \\
\text { logische Korrespondenzblatt } 2 \text { (2015) } \\
237-247 \text {. }\end{array}$ \\
\hline 1957 & $\begin{array}{l}\text { As an anepigraphic } \\
\text { monument, it is not in- } \\
\text { cluded in his epigraphic } \\
\text { list. }\end{array}$ & Cat. no. 31. abb. 16. & $\begin{array}{l}\text { See also SZABÓ, CS.: Notes on a New } \\
\text { Cautes Statue from Apulum. Archaeo- } \\
\text { logische Korrespondenzblatt } 2 \text { (2015) } \\
237-247 .\end{array}$ \\
\hline $1958-59$ & Cat. no. 12 . & Cat. no. 30. abb. 77. & \\
\hline 1960 & Cat. no. 13 . & Cat. no. 33 . & \\
\hline 1961 & $\begin{array}{l}\text { Cat. no. } 317 . \\
\text { C-G wrongly deems it } \\
\text { as an uncertain inscrip- } \\
\text { tion, although it was } \\
\text { certainly found in the } \\
\text { Oancea Mithraeaum. } \\
\end{array}$ & Cat. no. 34 . & \\
\hline 1962 & Cat. no. 14. & Cat. no. 35 . & \\
\hline 1963 & Cat. no. 15 . & Cat. no. 36. & \\
\hline 1964 & Cat. no. 16. & Cat. no. 37. & \\
\hline 1965 & Cat. no. 17. & Cat. no. 38. & \\
\hline 1966 & $\begin{array}{l}\text { Does not appear as } \\
\text { Mithraic inscription. }\end{array}$ & \begin{tabular}{|l|} 
Did not accept it as \\
Mithraic. SICOE (n. 32) \\
28, n. 96. \\
\end{tabular} & $\begin{array}{l}\text { The dedication is for Jupiter Optimus } \\
\text { Maximus, but the altar seems to belong } \\
\text { to the Oancea Mithraeum. }\end{array}$ \\
\hline 1967 & $\begin{array}{l}\text { As an anepigraphic } \\
\text { monument, it is not in- } \\
\text { cluded in his epigraphic } \\
\text { list. }\end{array}$ & $\begin{array}{l}\text { Did not accept it as } \\
\text { Mithraic. SiCOE (n. 32) } \\
\text { 28, n. } 96 .\end{array}$ & $\begin{array}{l}\text { It could be the representation of a torch- } \\
\text { bearer. See also SzABÓ, CS.: Notes on } \\
\text { a New Cautes Statue from Apulum. } \\
\text { Archaeologische Korrespondenzblatt } 2 \\
\text { (2015) 237-247. }\end{array}$ \\
\hline 1968 & $\begin{array}{l}\text { Cat. no. } 323 \text {. } \\
\text { Lists among the uncer- } \\
\text { tain dedications, possi- } \\
\text { bly to Sol. }\end{array}$ & $\begin{array}{l}\text { Did not accept it as } \\
\text { Mithraic. SICOE (n. 32) } \\
\text { 28, n. } 96 .\end{array}$ & \\
\hline
\end{tabular}




\begin{tabular}{|c|c|c|c|}
\hline 1969 & $\begin{array}{l}\quad \text { Cat. no. } 322 \text {. } \\
\text { Lists it among the un- } \\
\text { certain dedications, pos- } \\
\text { sibly to Sol. }\end{array}$ & $\begin{array}{l}\text { Did not accept it as } \\
\text { Mithraic. SICOE (n. 32) } \\
\text { 28, n. } 96 .\end{array}$ & \\
\hline 1970 & $\begin{array}{l}\quad \text { Cat. no. } 326 . \\
\text { Lists it among the un- } \\
\text { certain dedications, pos- } \\
\text { sibly to Sol. }\end{array}$ & $\begin{array}{l}\text { Did not accept it as } \\
\text { Mithraic inscription }\end{array}$ & $\begin{array}{l}\text { It was discovered in the area of the } \\
\text { Asclepieion. See } D M A \text {. }\end{array}$ \\
\hline 1971 & $\begin{array}{l}\text { Cat. no. } 137 . \\
\text { Wrongly identified it } \\
\text { as a dedication to Deus } \\
\text { Aeternus. }\end{array}$ & $\begin{array}{l}\text { Did not accept it as } \\
\text { Mithraic. SICOE (n. 32) } \\
\text { 28, n. } 96 .\end{array}$ & $\begin{array}{l}\text { It was discovered in the area of the As- } \\
\text { clepieion. See } D M A \text {. }\end{array}$ \\
\hline 1972 & $\begin{array}{l}\text { As an anepigraphic } \\
\text { monument, it is not in- } \\
\text { cluded in his epigraphic } \\
\text { list. }\end{array}$ & Cat. no. 40 abb. 25 . & \\
\hline 1973 & $\begin{array}{l}\text { As an anepigraphic } \\
\text { monument, it is not in- } \\
\text { cluded in his epigraphic } \\
\text { list. }\end{array}$ & Cat. no. 39. abb. 72 . & $\begin{array}{l}\text { Sicoe identifies it as a monument from } \\
\text { the Municipium Septimium. The exact } \\
\text { findspot is unknown. }\end{array}$ \\
\hline 1974 & $\begin{array}{l}\text { As an anepigraphic } \\
\text { monument, it is not in- } \\
\text { cluded in his epigraphic } \\
\text { list. }\end{array}$ & Cat. no. 42 , abb. 66 . & \\
\hline $1975-76$ & Cat. no. 18. & Cat. no. 41. abb. 95. & \\
\hline 1977 & Cat. no. 19. & Cat. no. 55 . & \\
\hline 1978 & & $\begin{array}{l}\text { Did not accept it as } \\
\text { Mithraic. SICOE (n. 32) } \\
\text { 28, n. } 96 .\end{array}$ & $\begin{array}{l}\text { Vermaseren already stated that the in- } \\
\text { scriptions interpreted by Cumont as be- } \\
\text { longing to a mithraeum could belong to } \\
\text { a shrine of Diana (CIL III } 1095,1096 \text { ). } \\
\text { These could belong to the Liber Pater } \\
\text { shrine. }\end{array}$ \\
\hline $1979-80$ & Cat. no. 20. & Cat. no. 45 , abb. 107. & \\
\hline $1981-82$ & Cat. no. 21. & Cat. no. 44 , abb. 36 . & \\
\hline $1983-84$ & $\begin{array}{l}\text { Cat. no. } 321 . \\
\text { Probably a dedication } \\
\text { to Sol-Helios. }\end{array}$ & $\begin{array}{l}\text { Did not accept it as } \\
\text { Mithraic. SICOE (n. 32) } \\
\text { 28, n. } 96 .\end{array}$ & $\begin{array}{l}\text { Vermaseren's description is not clear. } \\
\text { After the restauration it was clear that } \\
\text { the altar does not represents a snake and } \\
\text { a bull. }\end{array}$ \\
\hline 1985 & & Cat. no. 50, abb. 69 . & $\begin{array}{l}\text { Could be from the same context as that } \\
\text { of CIMRM } 2186 \text {. }\end{array}$ \\
\hline 1986 & & & $\begin{array}{l}\text { Identical with CIMRM 1938. See SZA- } \\
\text { BÓ, CS. - BouNEGRU, G. - SAVA, V.: } \\
\text { Mithras Rediscovered. Notes on the } \\
\text { CIMRM 1938. Ziridava } 28 \text { (2014) 149- } \\
156 .\end{array}$ \\
\hline 1987 & & Cat. no. 254, abb. 20. & Not sure whether it represents Mithras \\
\hline 1988 & & Cat. no. 255. abb. 21. & Not sure whether it represents Mithras \\
\hline $1989-90$ & $\begin{array}{l}\text { Cat. no. } 270 . \\
\text { Lists it among the un- } \\
\text { certain inscriptions. }\end{array}$ & Cat. no. 54 . & $\begin{array}{l}\text { The reading of the inscription is uncer- } \\
\text { tain }\end{array}$ \\
\hline
\end{tabular}




\begin{tabular}{|c|c|c|c|}
\hline 1991 & & Cat. no. 48 , abb. 4. & $\begin{array}{l}\text { Could belong to the so called Kaftal } \\
\text { Mithraeum. }\end{array}$ \\
\hline $1992-93$ & Cat. no. 22. & Cat. no. 47. & \\
\hline 1994 & & Cat. no. 49 , abb. 5 . & \\
\hline $1995-96$ & $\begin{array}{l}\text { Did not accept it as } \\
\text { Mithraic. }\end{array}$ & $\begin{array}{l}\text { Did not accept it as } \\
\text { Mithraic. }\end{array}$ & $\begin{array}{l}\text { The inscription is dedicated to Bonus } \\
\text { Puer, who probably had a sanctuary in } \\
\text { Apulum. }\end{array}$ \\
\hline 1997 & $\begin{array}{l}\text { Did not accept it as } \\
\text { Mithraic. }\end{array}$ & $\begin{array}{l}\text { Did not accept it as } \\
\text { Mithraic. }\end{array}$ & $\begin{array}{l}\text { The inscription is dedicated to Bonus } \\
\text { Puer, who probably had a sanctuary in } \\
\text { Apulum. }\end{array}$ \\
\hline 1998 & $\begin{array}{l}\text { Cat. no. } 324 . \\
\text { Enrolls it among the } \\
\text { uncertain inscriptions, } \\
\text { probably to Sol. }\end{array}$ & $\begin{array}{l}\text { Did not accept it as } \\
\text { Mithraic. }\end{array}$ & \\
\hline 1999 & $\begin{array}{l}\text { Cat. no. } 320 . \\
\text { Enrolls it among the } \\
\text { uncertain inscriptions, } \\
\text { probably to Sol. }\end{array}$ & $\begin{array}{l}\text { Did not accept it as } \\
\text { Mithraic. }\end{array}$ & \\
\hline 2000 & & Cat. no. 64, abb. 67. & $\begin{array}{l}\text { Could be from the territory of Apulum, } \\
\text { many of the Roman finds from Alvinc } \\
\text { were transported from Alba Iulia. }\end{array}$ \\
\hline $2001-02$ & Cat. no. 23. & Cat. no. 65 , abb. 96. & $\begin{array}{l}\text { Could be from the territory of Apulum, } \\
\text { many of the Roman finds from Alvinc } \\
\text { were transported from Alba Iulia. }\end{array}$ \\
\hline 2003 & Cat. no. 24 . & Cat. no. 66 . & $\begin{array}{l}\text { Could be from the territory of Apulum, } \\
\text { many of the Roman finds from Alvinc } \\
\text { were transported from Alba Iulia. }\end{array}$ \\
\hline $2004-05$ & Cat. no. 25 . & Cat. no. 63. abb. 27. & $\begin{array}{l}\text { Discovered at Oarda de Sus, but it could } \\
\text { be from the territory of Apulum. }\end{array}$ \\
\hline 2184 & & Cat. no. 223. abb. 6 . & $\begin{array}{l}\text { Could belong to the so called Kaftal } \\
\text { Mithraeum. }\end{array}$ \\
\hline 2185 & & Cat. no. 222 , abb. 18 . & $\begin{array}{l}\text { Preserved in the Batthyaneum, proba- } \\
\text { bly discovered in Apulum. }\end{array}$ \\
\hline 2186 & & Cat. no. 225. abb. 70 . & $\begin{array}{l}\text { Could belong to the same context with } \\
\text { CIMRM } 1985 \text {. }\end{array}$ \\
\hline \multirow[t]{2}{*}{2188} & & Cat. no. 224. abb. 11. & Probably discovered in Apulum. \\
\hline & & Cat. no. 22. & $\begin{array}{l}\text { Was discovered during the excavation } \\
\text { near the Liber Pater shrine. Not certain, } \\
\text { if the context is a new mithraeum or not. } \\
\text { See DIACONESCU, A. - BOGDAN, D. - } \\
\text { CIUTÃ, B. - GLIGOR, M. - LIPOT, Ş. - } \\
\text { DOBOS, A. - MUSTATĂ, S. - ÖTVÖS, } \\
\text { K. B. - PÁNCZÉL, SZ. P. - VASS, L. - } \\
\text { FIEDLER, M. - GRUNEWALD, H. M. - } \\
\text { HÖPKEN, K.: Alba Iulia, jud. Alba (Apu- } \\
\text { lum). Punct: cartierul Partoş. Cod sit: } \\
\text { 1026.13. CCAR, Campania } 2013 \text { Ora- } \\
\text { dea 2014, 100-101. }\end{array}$ \\
\hline
\end{tabular}




\begin{tabular}{|c|c|c|}
\hline $\begin{array}{l}\text { Cat. no. } 327 . \\
\text { Lists it among the un- } \\
\text { certain inscriptions, } \\
\text { probably dedicated to } \\
\text { Sol. }\end{array}$ & Cat. no. 27. & \\
\hline & Cat. no. 28. & $\begin{array}{l}\text { Was discovered during the excavation } \\
\text { near the Liber Pater shrine. Not certain, } \\
\text { whether the context is a new mithraeum } \\
\text { or not. See DIACONESCU ET AL.: Alba } \\
\text { Iulia, jud. Alba (Apulum). Punct: car- } \\
\text { tierul Partoş. Cod sit: } 1026.13 \text {. CCAR, } \\
\text { Campania 2013 Oradea 2014, 100-101. }\end{array}$ \\
\hline & Cat. no. 43. & $\begin{array}{l}\text { Could belong to the Mithraeum of Oan- } \\
\text { cea. See SzABÓ, CS.: Placing the Gods. } \\
\text { Sanctuaries and Sacralized Spaces in the } \\
\text { Settlements of Apulum. Revista Docto- } \\
\text { ranzilor in istorie veche şi arhelogie } 3 \\
\text { (2015) 123-160. }\end{array}$ \\
\hline Cat. no. 26. & Cat. no. 53. & \\
\hline & & $\begin{array}{l}\text { Statue of Cautes with bucranium: found } \\
\text { in secondary position in the Vauban fort. } \\
\text { See SzABÓ, CS.: Notes on a New Cautes } \\
\text { Statue from Apulum. Archaeologische } \\
\text { Korrespondenzblatt } 2 \text { (2015) 237-247 } \\
\text { (fig. 3). }\end{array}$ \\
\hline & & $\begin{array}{l}\text { Mithraic column: discovered on the } \\
\text { black market. Probably from the mith- } \\
\text { raeum of Károly Pap. See SZABÓ, CS. - } \\
\text { BODA, I. - TIMOC, C.: Notes on a New } \\
\text { Mithraic Inscription from Dacia. In AR- } \\
\text { DEVAN, R. - BEU-DACHIN, E. (eds): } \\
\text { Mensa Rotunda Epigraphica Napocen- } \\
\text { sis. Cluj-Napoca 2016, 91-105 (fig. 4). }\end{array}$ \\
\hline & & $\begin{array}{l}\text { Mithraeum discovered in } 2008 \text { and ex- } \\
\text { cavated systematically between } 2013 \\
\text { and 2016. See also: RUSTOIU, A. - } \\
\text { EGRI, M. - MCCARTY, M. - INEL, C.: } \\
\text { Apulum-Mithraeum III Project } 2014 . \\
\text { Alba Iulia, punct: cartier Cetate. In Cro- } \\
\text { nica cercetarilor arheologice din Roma- } \\
\text { nia. Bucuresti 2015, 19-21 and 260- } \\
\text { 261; EGRI, M. - MCCARTY, M. - RUS- } \\
\text { TOIU, A. - INEL, C.: A New Mithraic } \\
\text { Community at Apulum (Alba Iulia, } \\
\text { Romania), ZPE 205, 2018, 268-276. } \\
\text { Several important inscriptions and } \\
\text { small finds (fig. 5). }\end{array}$ \\
\hline
\end{tabular}




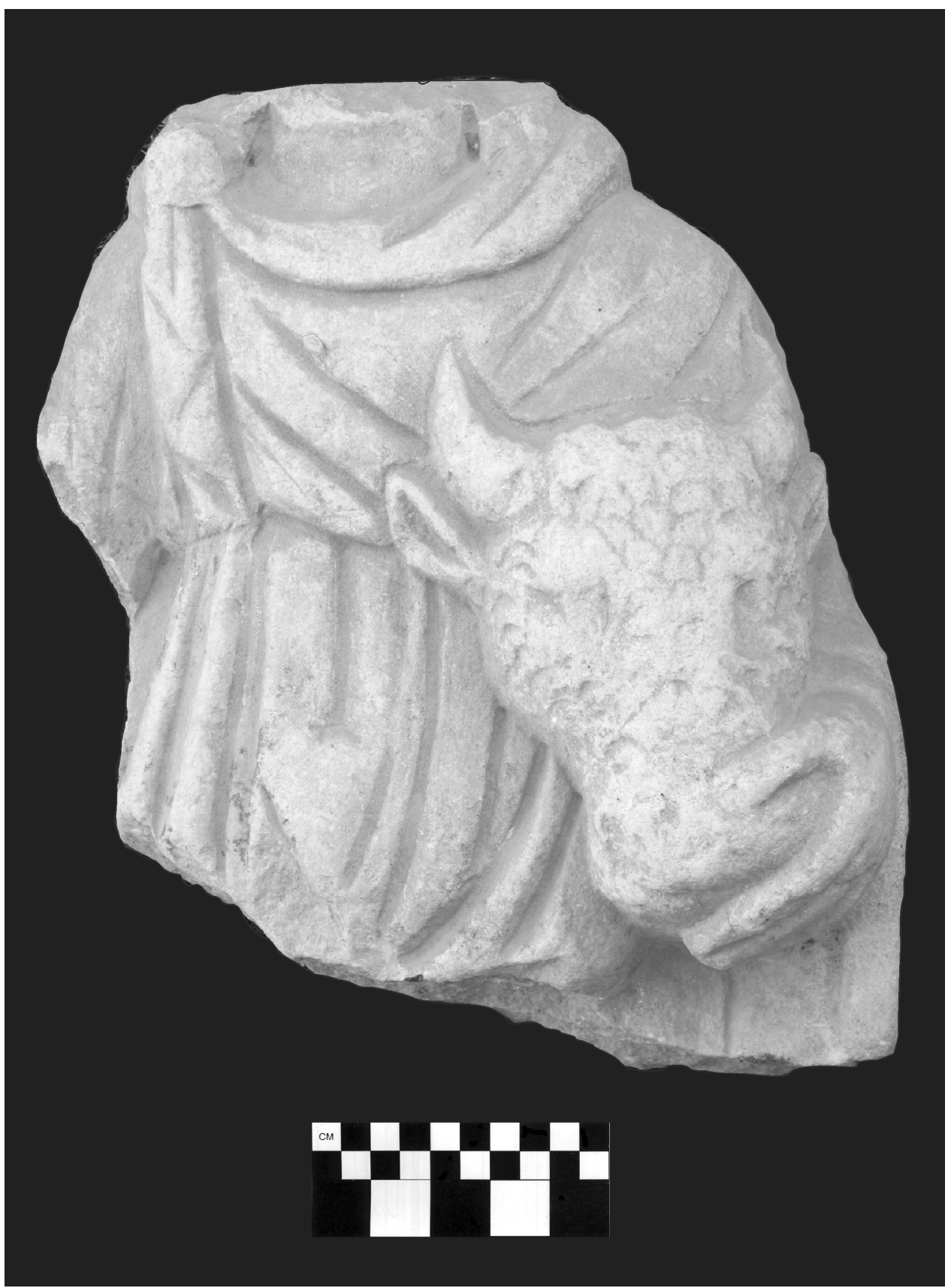

Fig. 3. Cautes with bucranium from Apulum (after SZABÓ 2015, 238, fig. 1a) 


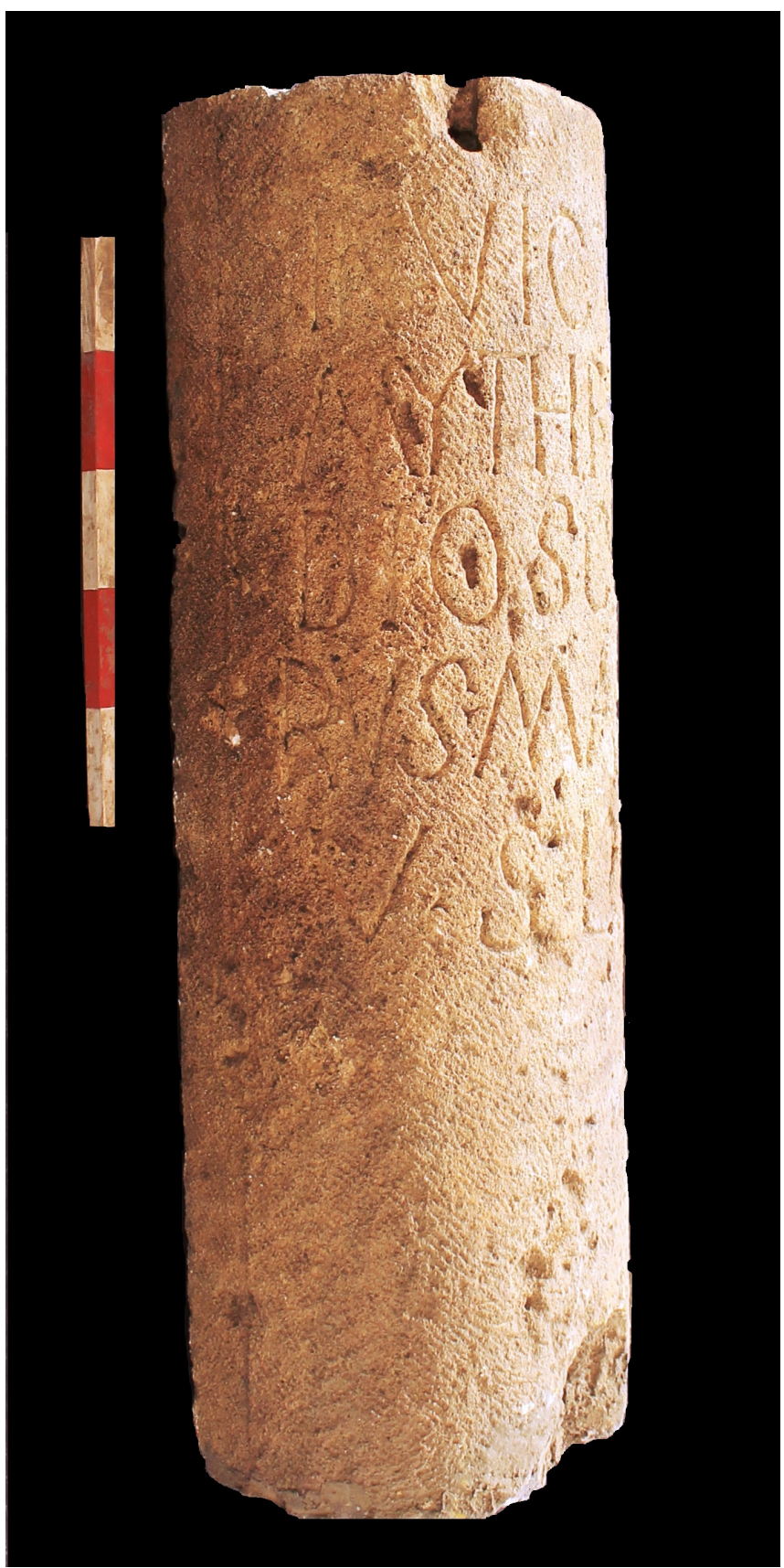

Fig. 4. Votive column from Apulum (after SzABÓ-BoDA-TIMOC 2016, 102, pl. 1.2) 


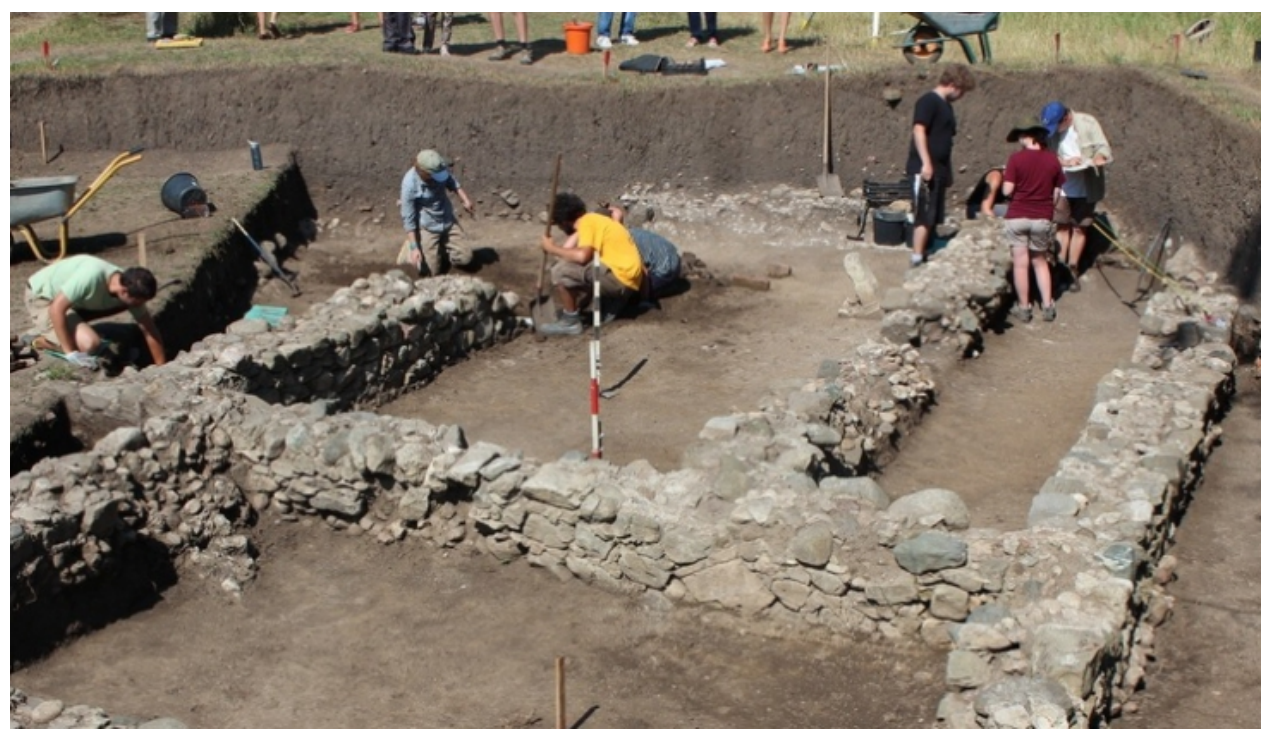

Fig. 5. Mithraeum discovered in 2008 and excavated recently in Apulum (RUSTOIU ET AL. 2015)

\section{OzD}

\begin{tabular}{|c|c|c|c|}
\hline CIMRM & $\begin{array}{c}\text { CARBÓ-GARCIA } \\
\text { (n. 31) }\end{array}$ & SICOE (n. 32) & NEW FINDS OR COMMENTS \\
\hline Cat. no. 42. & $\begin{array}{l}\text { Cat. no. 56. abb. 26. } \\
\text { Lists it among the finds } \\
\text { from the territorium } \\
\text { Apulensis. }\end{array}$ & \\
\hline
\end{tabular}

\section{BOIAN $^{39}$}

\begin{tabular}{|c|l|c|c|}
\hline CIMRM & \multicolumn{1}{|c|}{$\begin{array}{c}\text { CARBÓ-GARCIA } \\
\text { (n. 31) }\end{array}$} & SICOE (n. 32) & NEW FINDS OR COMMENTS \\
\hline 1934 & $\begin{array}{l}\text { As an anepigraphic } \\
\text { monument, it is not in- } \\
\text { cluded in his epigraphic } \\
\text { list. }\end{array}$ & $\begin{array}{l}\text { Cat. no. 57. } \\
\text { Lists it among the finds } \\
\text { from the territorium } \\
\text { Apulensis. }\end{array}$ & Lupa 9883. \\
\hline
\end{tabular}

${ }^{39}$ There were no other Roman finds identified in this settlement. The altar could belong to another site and reused in Medieval times in Alsóbajom. 


\section{SĂCĂDATE}

\begin{tabular}{|c|c|c|c|}
\hline CIMRM & $\begin{array}{c}\text { CARBÓ-GARCIA } \\
\text { (n. 31) }\end{array}$ & SICOE (n. 32) & NEW FINDS OR COMMENTS \\
\hline Cat. no. 56. & $\begin{array}{l}\text { Cat. no. 58. } \\
\text { Lists it among the finds } \\
\text { from the territorium } \\
\text { Apulensis. }\end{array}$ & \\
\hline
\end{tabular}

\section{LOPADEA NOUĂ}

\begin{tabular}{|c|c|c|c|}
\hline CIMRM & $\begin{array}{c}\text { CARBÓ-GARCIA } \\
\text { (n. 31) }\end{array}$ & SICOE (n. 32) & NEW FINDS OR COMMENTS \\
\hline Cat. no. 36. & $\begin{array}{l}\text { Cat. no. 62 abb. 37. } \\
\text { Lists it among the finds } \\
\text { from the territorium } \\
\text { Apulensis. }\end{array}$ & \\
\hline
\end{tabular}

\section{PĂULENI}

\begin{tabular}{|c|c|c|c|}
\hline CIMRM & $\begin{array}{c}\text { CARBÓ-GARCIA } \\
\text { (n. 31) }\end{array}$ & SICOE (n. 32) & NEW FINDS OR COMMENTS \\
\hline 2011 & $\begin{array}{l}\text { Cat. no. 335. } \\
\text { Lists it among the un- } \\
\text { certain inscriptions, } \\
\text { probably to Sol. }\end{array}$ & $\begin{array}{l}\text { Did not accept it as } \\
\text { Mithraic inscription. } \\
\text { SiCOE (n. 32) 31, n. 129. }\end{array}$ & \\
\hline
\end{tabular}

\section{CINCȘOR}

\begin{tabular}{|c|c|c|c|}
\hline CIMRM & $\begin{array}{c}\text { CARBÓ-GARCIA } \\
\text { (n. 31) }\end{array}$ & SICOE (n. 32) & NEW FINDS OR COMMENTS \\
\hline 2012 & Cat. no. 31. & & $\begin{array}{l}\text { Vermaseren probably refers to a Mith- } \\
\text { raeum which seems to exist in Cincsor } \\
\text { where a Roman military settlement was } \\
\text { identified. }\end{array}$ \\
\hline 2013 & & Cat. no. 67. abb. 119. & \\
\hline 2014 & & Cat. no. 68. abb. 120. & \\
\hline 2015 & & Cat. no. 69. abb. 38. & \\
\hline 2016 & & Cat. no. 70. & \\
\hline
\end{tabular}




\begin{tabular}{|l|l|l|l|}
\hline 2017 & \multicolumn{1}{|c|}{ Cat. no. 71.} & $\begin{array}{l}\text { Uncertain whether these small fragments } \\
\text { are part of one or more reliefs. There } \\
\text { were no photos published about these } \\
\text { finds. }\end{array}$ \\
\hline
\end{tabular}

$\operatorname{MiCIA}^{40}$

\begin{tabular}{|c|c|c|c|}
\hline CIMRM & $\begin{array}{c}\text { CARBÓ-GARCIA } \\
\text { (n. 31) }\end{array}$ & SICOE (n. 32) & NEW FINDS OR COMMENTS \\
\hline 2018 & & Cat. no. 195. abb. 33. & \\
\hline 2019 & Cat. no. 37. & Cat. no. 202. & \\
\hline 2022 & Cat. no. 39. & Cat. no. 201. & \\
\hline 2023 & & Cat. no. 196. abb. 60. & \\
\hline 2024 & & & $\begin{array}{l}\text { Vermaseren cites Buday's article from } \\
1916, \text { but does not publish the photog- } \\
\text { raphy of the relief. }\end{array}$ \\
\hline 2025 & Cat. no. 40. & Cat. no. 198. & \\
\hline & Cat. no. 199. abb. 129. & \\
\hline & $\begin{array}{l}\text { Cat. no. 333. } \\
\text { Lists it among the un- } \\
\text { certain inscriptions. Pos- } \\
\text { sibly a dedication to } \\
\text { Sol Invictus. }\end{array}$ & Cat. no. 200. & $\begin{array}{l}\text { The inscription is the only epigraphic } \\
\text { attestation of a sanctuary. It is more } \\
\text { plausible, that it refers to Mithras than } \\
\text { Sol Invictus. See: SzABÓ, Cs.: The Cult } \\
\text { of Mithras in Apulum: Communities } \\
\text { and Individuals. In ZERBINI, L. (ed.): } \\
\text { Culti e religiositá nelle province danu- } \\
\text { biane. Bologna 2015, 409, n. 24. }\end{array}$ \\
\hline
\end{tabular}

CIOROIUL NOU ${ }^{41}$

\begin{tabular}{|c|c|c|l|}
\hline CIMRM & $\begin{array}{c}\text { CARbÓ-GARCIA } \\
\text { (n. 31) }\end{array}$ & SiCOE (n. 32) & \multicolumn{1}{|c|}{ NEW FINDS OR COMMENTS } \\
\hline 2026 & & & $\begin{array}{l}\text { Vermaseren confused the Serbian Dub- } \\
\text { ljane with the Romanian Calan. Not } \\
\text { from Roman Dacia. }\end{array}$ \\
\hline 2162 & Cat. no. 28. & Cat. no. 230. & $\begin{array}{l}\text { There is a letter or symbol similar to a } \\
\text { P on the back of the altar. }\end{array}$ \\
\hline
\end{tabular}

${ }^{40}$ The existence of a Mithraeum from Micia is confirmed by epigraphic sources. The large number of the finds also suggest the presence of a sanctuary, which was unfortunately not attested on the field. or Malva.

${ }^{41}$ The ancient name of the settlement is uncertain. For a long time it was associated with Aquae 


\section{COLONIA SARMIZEGETUSA ${ }^{42}$}

\begin{tabular}{|c|c|c|c|}
\hline CIMRM & $\begin{array}{l}\text { CARBÓ-GARCIA } \\
\text { (n. 31) }\end{array}$ & SiCOE (n. 32) & NEW FINDS OR COMMENTS \\
\hline $2006-7$ & Cat. no. 57. & Cat. no. 188. abb. 71. & $\begin{array}{l}\text { Attested at Doștat, it comes very proba- } \\
\text { bly from Sarmizegetusa. }\end{array}$ \\
\hline 2008 & Cat. no. 58. & Cat. no. 194. & $\begin{array}{l}\text { Attested at Doştat, it comes very proba- } \\
\text { bly from Sarmizegetusa. }\end{array}$ \\
\hline $2009-10$ & Cat. no. 59 . & Cat. no. 189. & $\begin{array}{l}\text { Attested at Doștat, it comes very proba- } \\
\text { bly from Sarmizegetusa. }\end{array}$ \\
\hline $2020-21$ & Cat. no. 38 . & Cat. no. 184. abb.76. & $\begin{array}{l}\text { Vermaseren mentioned the monument } \\
\text { as one from Micia. The first publisher, } \\
\text { Neigebaur mentioned clearly among } \\
\text { the finds from Sarmizegetusa. }\end{array}$ \\
\hline 2027 & & & $\begin{array}{l}\text { On the mithraeum, see also SzABÓ, CS. - } \\
\text { BODA, I.: Ulpia Traiana Sarmizegetusa } \\
\text { (n. 42). }\end{array}$ \\
\hline $2028-29$ & Cat. no. 68 . & Cat. no. 172 . & \\
\hline 2030 & Cat. no. 69. & Cat. no. 175. & \\
\hline 2031 & Cat. no. 70 . & Cat. no. 176. & \\
\hline 2032 & Cat. no. 71 . & Cat. no. 173. & \\
\hline 2033 & & & $\begin{array}{l}\text { The small finds of the mithraeum were } \\
\text { mentioned in one single entry. See also } \\
\text { SzABÓ, Cs.: Notes on the Mithraic Small } \\
\text { Finds from Sarmizegetusa (n. 21). }\end{array}$ \\
\hline $2034-35$ & Cat. no. 72 . & Cat. no. 119. abb. 79. & \\
\hline 2036 & & Cat. no. 118. abb. 53. & \\
\hline 2037 & & Cat. 116. abb. 135. & \\
\hline $2038-2041$ & & & $\begin{array}{l}\text { In many cases, M. Vermaseren did not } \\
\text { realise that some of the fragments be- } \\
\text { long to the same relief. Sicoe's new cata- } \\
\text { logue reorganized some of the larger } \\
\text { pieces. }\end{array}$ \\
\hline 2042 & & Cat. no. 131. abb. 99. & \\
\hline 2043 & & Cat. no. 130. abb. 31. & \\
\hline $2044-45$ & Cat. no. 74 . & Cat. no. 129. abb. 89. & \\
\hline $2046-47$ & Cat. no. 75 . & Cat. no. 126. abb. 81. & \\
\hline
\end{tabular}

${ }^{42}$ One of the biggest Mithraic discoveries of the Roman Empire was unearthed in Sarmizegetusa in the 1880's by Pál Király. Before that, only few Mithraic monuments were known from the settlement (CIMRM 2020 for example). It is still uncertain, if all the finds of Pál Király belong to a single sanctuary or it proves the existence of a local-regional workshop of Mithraic reliefs. The quantity of finds is the biggest ever discovered on a single site. It could be also a later Roman spolia, as in many of the mithraea we can attest this phenomena. D. Alicu suggests the possibility of the existence of a second mithraeum too, although it was not identified on the field. See also: BODA, I.: Ulpia Traiana Sarmizegetusa and the Archaelogical Research Carried out between 1881 and 1893. Studia Antiqua et Archaeologica 20 (2014) 307-351; SZABÓ: Notes (n. 21). 


\begin{tabular}{|c|c|c|c|}
\hline $2048-49$ & Cat. no. 76. & Cat. no. 120. abb. 80. & \\
\hline 2050 & & Cat. no. 114. abb. 52. & \\
\hline 2051 & & Cat. no. 113. abb. 92. & \\
\hline 2052 & & Cat. no. 111. abb. 98. & \\
\hline 2053 & & Cat. no. 109. abb. 127. & \\
\hline 2054 & & Cat. no. 158. & \\
\hline 2055 & & Cat. no. 103. abb. 88. & \\
\hline 2056 & & Cat. no. 112. abb. 134. & \\
\hline 2057 & & $\begin{array}{l}\text { Cat. no. } 106 . \\
\text { abb. } 132-33 \text {. }\end{array}$ & \\
\hline $2058=2093$ & & Cat. no. 98. abb. 125. & \\
\hline 2059 & & Cat. no. 104. abb. 97. & \\
\hline $2060-61$ & Cat. no. 77. & Cat. no. 105. abb. 51. & \\
\hline $\begin{array}{c}2062= \\
2092 \\
=2094\end{array}$ & & $\begin{array}{l}\text { Cat. no. } 102 . \\
\text { abb. } 48-50 .\end{array}$ & \\
\hline 2063 & & Cat. no.100. abb. 64 . & \\
\hline $2064-65$ & Cat. no. 78. & Cat. no. 97. abb. 47. & \\
\hline $2066-67$ & Cat. no. 79 . & $\begin{array}{l}\text { Cat. no. } 101 . \\
\text { abb. } 28-29 .\end{array}$ & \\
\hline $2068-69$ & Cat. no. 80 . & Cat. no. 88. abb. 45. & \\
\hline 2070 & & Cat. no. 94. & \\
\hline 2071 & & Cat. no. 95. abb. 123. & \\
\hline 2072 & & Cat. no. 96. abb. 124. & \\
\hline $2073-74$ & Cat. no. 81. & Cat. no. 82. abb. 40. & \\
\hline $2075-76$ & Cat. no. 82 . & Cat. no. 85. abb. 42. & \\
\hline 2077 & & Cat. no. 157. & $\begin{array}{l}\text { Recently identified it in the National } \\
\text { Museum of Banatului, Timisoara. } \\
\text { No. inv.: } 6507 .\end{array}$ \\
\hline 2078 & & Cat. no. 86. abb. 43. & \\
\hline 2079 & & Cat. no. 90 . & $\begin{array}{l}\text { Recently identified it in the National } \\
\text { Museum of Banatului, Timisoara. } \\
\text { No. inv.: } 7590 \text {. }\end{array}$ \\
\hline 2080 & & Cat. no. 91. & \\
\hline $2081-82$ & Cat. no. 83 . & Cat.no. 99. & \\
\hline 2083 & & Cat. no. 81. abb. 39. & \\
\hline 2084 & & Cat. no. 169. abb. 14. & \\
\hline 2085 & & Cat. no. 87. abb. 44. & \\
\hline 2086 & & Cat. no. 128. & \\
\hline 2087 & & Cat. no. 159. & \\
\hline 2089 & & Cat.no. 139. & \\
\hline 2090 & & $\begin{array}{l}\text { See the comments on } \\
\text { SICOE (n. 32) } 31, \text { n. } 129 .\end{array}$ & \\
\hline 2091 & & Cat. no. 160. abb. 100. & \\
\hline
\end{tabular}




\begin{tabular}{|c|c|c|c|}
\hline 2095 & & Cat. no. 161. & \\
\hline 2096 & & Cat. no. 154 . & \\
\hline 2097 & & Cat. no. 162. & \\
\hline 2098 & & Cat. no. 140. & \\
\hline 2099 & & Cat. no. 141. & \\
\hline 2100 & & Cat.no. 142. & \\
\hline 2101 & & Cat. no. 144. & \\
\hline 2102 & & Cat. no. 145 . & \\
\hline 2103 & & Cat. no. 146. & \\
\hline 2104 & & Cat. no. 148 & \\
\hline 2105 & & Cat. no. 149 . & \\
\hline 2106 & & Cat. no. 121. & \\
\hline 2107 & & Cat. no. 122. abb. 136. & \\
\hline 2108 & & Cat. no. 123. abb. 30. & \\
\hline 2109 & & Cat. no. 124. & \\
\hline 2110 & & Cat. no. 125 . & \\
\hline 2111 & & Cat. no. 132. abb. 137. & \\
\hline 2112 & & Cat. no. 163. abb. 139. & \\
\hline 2113 & & Cat. no. 164. abb. 140 & \\
\hline 2114 & & Cat. no. 133. abb. 138. & \\
\hline 2115 & & Cat. no. 134. & \\
\hline 2116 & & Cat. no. 135. & \\
\hline 2117 & & Cat. no. 136. & \\
\hline 2118 & & Cat. no. 137. & \\
\hline 2119 & & Cat. no. 127. & \\
\hline $2120-21$ & Cat. no. $84 a$. & Cat. no. 169. abb. 14. & \\
\hline $2122-23$ & Cat. no. $84 \mathrm{~b}$. & Cat. no. 170. abb. 15. & \\
\hline 2124 & & Cat. no. $72-78$. & \\
\hline 2125 & & Cat. no. 152. & \\
\hline 2126 & & Cat. no. 151. & \\
\hline 2127 & & Cat. no. 165. & \\
\hline 2128 & & Cat. no. 93. abb. 122. & \\
\hline 2129 & & Cat. no. 147. & \\
\hline 2130 & & Cat. no. 92. abb. 46. & \\
\hline 2131 & & Cat. no. 107. & \\
\hline 2132 & & Cat. no. 108. abb. 126. & \\
\hline 2133 & & Cat. no. 110. & \\
\hline 2134 & & Cat. no. 171. abb. 10. & \\
\hline $2135-36$ & Cat. no. 85 . & Cat. no. 83. abb. 41. & \\
\hline $2137-38$ & Cat. no. 86. & Cat. no. 84. abb. 112. & $\begin{array}{l}\text { Recently identified it in the National } \\
\text { Museum of Banatului in Timisoara. } \\
\text { Inv. no.: } 7596 .\end{array}$ \\
\hline
\end{tabular}




\begin{tabular}{|c|c|c|c|}
\hline 2139 & & Cat. no. 80 . & \\
\hline 2140 & & Cat. no. 89. abb. 129. & See also CIMRM 2200. \\
\hline 2141 & & Cat. no. 177 . & \\
\hline $2142-43$ & Cat. no. 87. & Cat. no. 178. abb. 32 . & \\
\hline 2144 & Cat. no. 88 . & Cat. no. 193. & \\
\hline 2145 & & & $\begin{array}{l}\text { Not accepted as a Mithraic inscription, } \\
\text { although it was published in CIL and } \\
\text { Cumont in the same context as the pre- } \\
\text { vious one. }\end{array}$ \\
\hline 2146 & Cat. no. 89 . & Cat. no. 191. & \\
\hline 2147 & & Cat. no. 192. & \\
\hline 2148 & $\begin{array}{l}\quad \text { Cat. no. } 340 \text {. } \\
\text { Lists it among the in- } \\
\text { scriptions dedicated to } \\
\text { Sol Invictus. }\end{array}$ & & \\
\hline $2149-50$ & Cat. no. 90. & Cat. no. 179. abb. 54. & \\
\hline 2151 & & Cat. no. 190. abb. 9. & \\
\hline \multirow[t]{7}{*}{2152} & & Cat. no. 180. abb. 55 . & \\
\hline & & Cat. no. 181. & $\begin{array}{l}\text { Discovered it in } 1966 \text { on the South- } \\
\text { West corner of the Roman city. It could } \\
\text { indicate the position of the sanctuary. }\end{array}$ \\
\hline & & Cat. no. 182. & The same context as the previous one. \\
\hline & & Cat. no. 183. & $\begin{array}{l}\text { Discovered it at Poiana (jud. Gorj). Not } \\
\text { sure whether it comes from Sarmizege- } \\
\text { tusa. }\end{array}$ \\
\hline & & Cat. no. 185. abb. 56. & \\
\hline & & Cat. no. 186. & \\
\hline & & Cat. no. 187. & \\
\hline
\end{tabular}

\section{TIBISCUM $^{43}$}

\begin{tabular}{|c|c|c|c|}
\hline CIMRM & $\begin{array}{c}\text { CARBÓ-GARCIA } \\
\text { (n. 31) }\end{array}$ & SiCOE (n. 32) & NEW FINDS OR COMMENTS \\
\hline 2153 & Cat. no. 67. & Cat. no. 203. & \\
\hline 2189 & & Cat. no. 220. abb. 141. & $\begin{array}{l}\text { The relief fragment was photographed } \\
\text { and published by Vermaseren with the } \\
\text { help of Dorin Popescu in Bucuresti in } \\
\text { 1958. Later it became part of the collec- } \\
\text { tion from the Museum of Banat. After } \\
\text { the opinion of I. Boda and C. Timoc, } \\
\text { the relief was discovered in Tibiscum: } \\
\text { BoDA I. - TIMOC, C.: The Sacred To- }\end{array}$ \\
\hline
\end{tabular}

${ }^{43}$ The existence of a mithraeum is supposed in this settlement too, based on the important altar of Hermadio and the archaeological context of the discoveries. 


\begin{tabular}{|l|l|}
\hline & $\begin{array}{l}\text { pography of Tibiscum. In NEMETI, S. - } \\
\text { BODA, I. - SzABÓ, Cs. (eds): New Per- } \\
\text { spectives in the Study of Roman Relig- } \\
\text { ion in Dacia [Studia Historia Universi- } \\
\text { tatis Babes-Bolyai]. Cluj-Napoca 2016, } \\
41-62 .\end{array}$ \\
\hline
\end{tabular}

\section{DIERNA $^{44}$}

\begin{tabular}{|c|c|c|c|}
\hline CIMRM & $\begin{array}{c}\text { CARBÓ-GARCIA } \\
\text { (n. 31) }\end{array}$ & SiCOE (n. 32) & NEW FINDS OR COMMENTS \\
\hline 2154 & & Cat. no. 217. abb. 58. & \\
\hline & & Cat. no. 218. & \\
\hline & Cat. no. 32. & Cat. no. 204. & $\begin{array}{l}\text { Uncertain provenience } \\
\text { to the same context as the previous one. }\end{array}$ \\
\hline & & &
\end{tabular}

\section{POJEJENA ${ }^{45}$}

\begin{tabular}{|l|c|c|c|}
\hline CIMRM & $\begin{array}{c}\text { CARBÓ-GARCIA } \\
\text { (n. 31) }\end{array}$ & SiCOE (n. 32) & NEW FINDS OR COMMENTS \\
\hline & & Cat. no. 205. & \\
\hline & Cat. no. 44. & Cat. no. 206. & \\
\hline & Cat. no. 43. & Cat. no. 207. abb. 115. & \\
\hline & & Cat. no. 208. abb. 68. & \\
\hline & & Cat. no. 209. abb. 101. & \\
\hline & Cat. no. 45. & Cat. no. 210. abb. 116. & \\
\hline & & Cat. no. 211. abb. 75. & \\
\hline & & Cat. no. 212. & \\
\hline & & Cat. no. 213. abb. 117. & \\
\hline & & Cat. no. 214. & \\
\hline & Cat. no. 46. & Cat. no. 215. & \\
\hline & & Cat. no. 216. & \\
& & abb. 101-102. & \\
\hline
\end{tabular}
finds.

${ }^{44}$ The existence of a mithraeum is supposed in this settlement based on the number of Mithraic

${ }^{45}$ The existence of a mithraeum is supposed in this settlement based on the number of Mithraic finds. The context of the finding is very problematic (in one of the corners of the Roman fort). It could have been either a late antique spolia or pertaining to the post-military phase of the fort. Pojejena - although it was listed among the finds from Dacia - very likely was under the administration of Moesiae. 


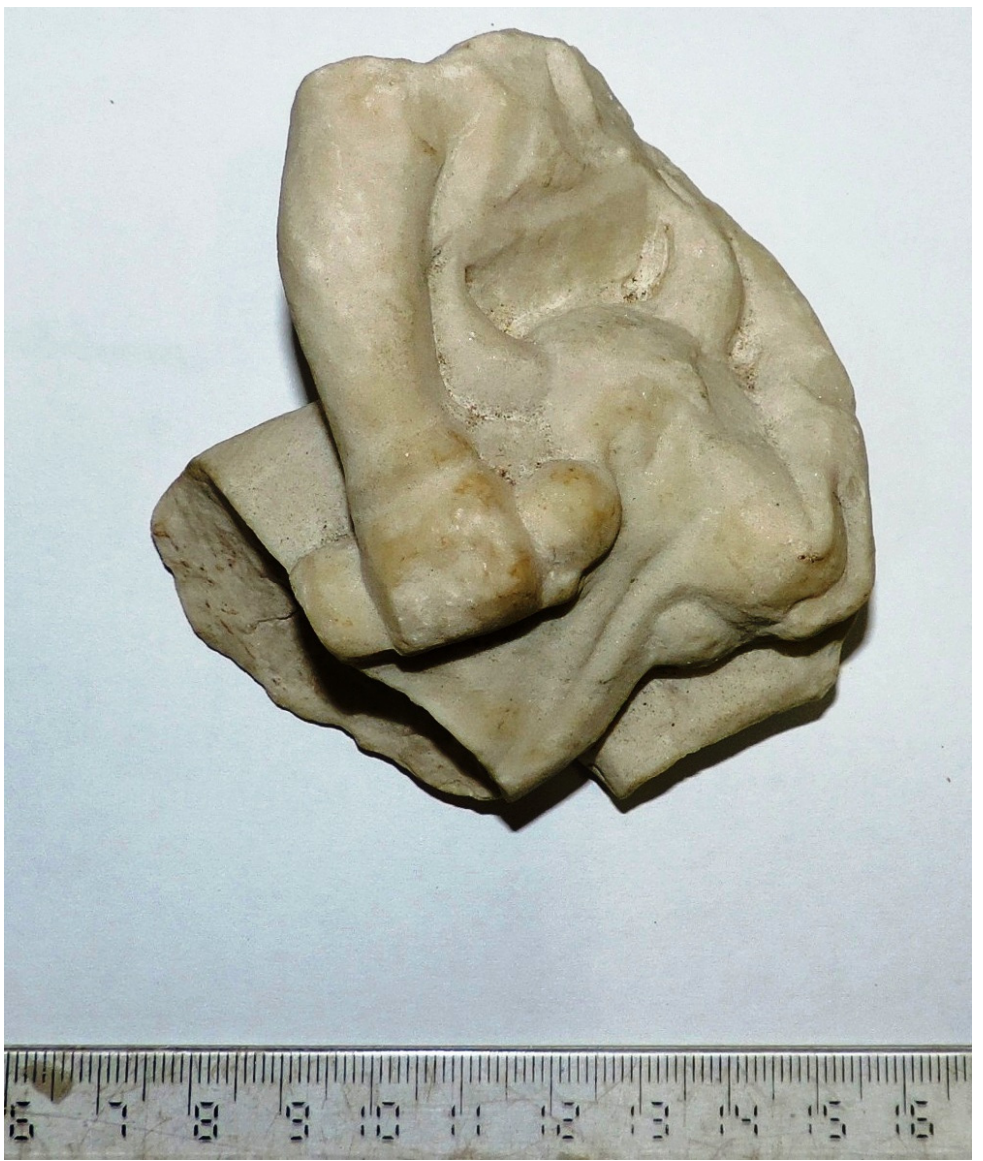

Fig. 6. Mithraic relief fragment representing Mithras killing the bull (GUDEA-BOZU 1977, photo by Ana C. Hamat, Museum of Banatului Montan, Resiţa, RO)

\begin{tabular}{|l|l|l|l|}
\hline & $\begin{array}{l}\text { GUDEA, N. - BOZU, O.: } \\
\text { A existat un sanctuary } \\
\text { mithraic la Pojejena? } \\
\text { Banatica 4 (1977) 125- } \\
126, \text { cat. no. 13. }\end{array}$ & $\begin{array}{l}\text { The small head was published as Mith- } \\
\text { ras. It could belong to one of the torch- } \\
\text { bearers too. }\end{array}$ \\
\hline & $\begin{array}{l}\text { GuDEA, N. - BOZU, O.: } \\
\text { A existat un sanctuary } \\
\text { mithraic la Pojejena? } \\
\text { Banatica 4 (1977) 125- } \\
126, \text { cat. no. 14. }\end{array}$ & $\begin{array}{l}\text { Mithras killing the bull fragment. The } \\
\text { inventory sheet dates the monument to } \\
\text { the 3rd-4th centuries AD (fig. 6). }\end{array}$ \\
\hline & & $\begin{array}{l}\text { Mithraic relief fragment: recently dis- } \\
\text { covered during the excavations in the } \\
\text { Roman fort, probably on the same spot } \\
\text { as the previous finds. Verbal confirma- } \\
\text { tion of B. Imola and C. Timoc. Prepared } \\
\text { for publication. }\end{array}$ \\
\hline
\end{tabular}




\section{DROBETA $^{46}$}

\begin{tabular}{|c|c|c|c|}
\hline CIMRM & $\begin{array}{c}\text { CARBÓ-GARCIA } \\
\text { (n. 31) }\end{array}$ & SICOE (n. 32) & NEW FINDS OR COMMENTS \\
\hline 2157 & & & $\begin{array}{l}\text { Vermaseren cites the work of Tudor, } \\
\text { who mentioned a relief from Oltenia, } \\
\text { Drobeta preserved in the National Mu- } \\
\text { seum of Bucuresti. Not confirmed by } \\
\text { any further researchers. }\end{array}$ \\
\hline 2158 & & & $\begin{array}{l}\text { Small bronze statuette with a Phrygian } \\
\text { cap discovered in Catunele de Motru. } \\
\text { No photos published. Impossible to con- } \\
\text { firm whether it is Mithraic or not. }\end{array}$ \\
\hline 2159 & & & Cat. no. 226. abb. 143. \\
\hline 2160 & & Cat. no. 227. abb. 13. & Disappeared. \\
\hline
\end{tabular}

\section{BUMBESTI-GORJ}

\begin{tabular}{|c|c|c|c|}
\hline CIMRM & $\begin{array}{c}\text { CARBÓ-GARCIA } \\
\text { (n. 31) }\end{array}$ & SICOE (n. 32) & NEW FINDS OR COMMENTS \\
\hline 2163 & Cat. no. 30. & Cat. no. 228. & \\
\hline
\end{tabular}

\section{BOTOSESTI-PAIA}

\begin{tabular}{|c|c|c|c|}
\hline CIMRM & $\begin{array}{c}\text { CARBÓ-GARCIA } \\
\text { (n. 31) }\end{array}$ & SICOE (n. 32) & NEW FINDS OR COMMENTS \\
\hline $2155-56$ & & Cat. no. 228. & \\
\hline
\end{tabular}

ROMULA $^{47}$

\begin{tabular}{|c|c|c|c|}
\hline CIMRM & $\begin{array}{c}\text { CARBÓ-GARCIA } \\
\text { (n. 31) }\end{array}$ & SICOE (n. 32) & NEW FINDS OR COMMENTS \\
\hline 2164 & & Cat. no. 231. abb. 144. & \\
\hline 2170 & & Cat. no. 236. abb. 7. & $\begin{array}{l}\text { The statue was probably part of the sanc- } \\
\text { tuary and used with oil lamps similarly } \\
\text { to the case study from Inveresk. }\end{array}$ \\
\hline
\end{tabular}

${ }^{46}$ Most of the finds are listed by Vermaseren as discovered in Transylvania.

${ }^{47}$ The mithraeum was possibly discovered in 1856 on the bank of the Teslui river. No further excavations were made.

${ }^{48}$ http://www.tertullian.org/rpearse/mithras/display.php?page=supp_Britain_Inveresk_Mithraeum. Last access: 13.02.2017. 


\begin{tabular}{|c|c|c|l|}
\hline 2171 & & Cat. no. 232. abb. 104. & \\
\hline $2172-73$ & Cat. no. 53. & Cat. no. 233. abb. 118. & \\
\hline $2174-76$ & & & $\begin{array}{l}\text { Uncertain Mithraic objects. See SICOE } \\
\text { (n. 32) 34, n. 175. }\end{array}$ \\
\hline 2177 & Cat. no. 54. & Cat. no. 237. & \\
\hline 2178 & & & $\begin{array}{l}\text { The relief-fragment could belong to a } \\
\text { Bacchic representation, too; uncertain } \\
\text { Mithraic nature. }\end{array}$ \\
\hline 2179 & & Cat. no. 234. & \\
\hline 2183 & Cat. no. 55. & Cat. no. 238. & \\
\hline & & Cat. no. 235. & \\
\hline
\end{tabular}

\section{SFINȚEŞTI}

\begin{tabular}{|c|c|c|c|}
\hline CIMRM & $\begin{array}{c}\text { CARBÓ-GARCIA } \\
\text { (n. 31) }\end{array}$ & SICOE (n. 32) & NEW FINDS OR COMMENTS \\
\hline & Cat. no. 62. & Cat. no. 239. & \\
\hline
\end{tabular}

\section{SLĂVENI ${ }^{49}$}

\begin{tabular}{|c|c|c|c|}
\hline CIMRM & $\begin{array}{c}\text { CARBÓ-GARCIA } \\
\text { (n. 31) }\end{array}$ & SICOE (n. 32) & NEW FINDS OR COMMENTS \\
\hline 2166 & & Cat. no. 242. abb. 90. & \\
\hline 2167 & & Cat. no. 241. abb. 109. & \\
\hline 2168 & & Cat. no. 240. abb. 94. & \\
\hline & & Cat. no. 243. abb. 110. & \\
\hline & & Cat. no. 244. abb. 145. & \\
\hline & & Cat. no. 245. abb. 130. & \\
\hline 2169 & Cat. no. 63. & Cat. no. 246. & \\
\hline 2169 & Cat. no. 64. & Cat. no. 247. & \\
\hline
\end{tabular}

\section{SUCIDAVA $^{50}$}

\begin{tabular}{|c|c|c|c|}
\hline CIMRM & $\begin{array}{c}\text { CARBÓ-GARCIA } \\
\text { (n. 31) }\end{array}$ & SICOE (n. 32) & NEW FINDS OR COMMENTS \\
\hline 2182 & & Cat. no. 248. & \\
\hline & & Cat. no. 249. abb. 131. & \\
\hline
\end{tabular}

${ }^{49}$ A mithraeum was discovered in 1837 and shortly published by V. Blaremberg.

${ }^{50}$ The existence of a mithraeum is based on the large amount of material found in the settlement. The exact findspot of the sanctuary is unknown. 


\begin{tabular}{|l|l|c|l|}
\hline & Cat. no. 66. & Cat. no. 250. & \\
\hline & Cat. no. 65. & Cat. no. 251. abb. 106. & \\
\hline
\end{tabular}

PeSTERA LUi TRAiAN

\begin{tabular}{|c|c|c|c|}
\hline CIMRM & $\begin{array}{c}\text { CARBÓ-GARCIA } \\
\text { (n. 31) }\end{array}$ & SICOE (n. 32) & NEW FINDS OR COMMENTS \\
\hline & & & $\begin{array}{l}\text { Uncertain context. Cumont mentioned } \\
\text { it as among the probable sanctuaries. } \\
\text { Rock carvings were reported by local } \\
\text { inhabitants. PINTILIE 1999-2000, 236. }\end{array}$ \\
\hline
\end{tabular}

\section{PESTERA VETERAN}

\begin{tabular}{|c|c|c|c|}
\hline CIMRM & $\begin{array}{c}\text { CARBÓ-GARCIA } \\
\text { (n. 31) }\end{array}$ & SICOE (n. 32) & NEW FINDS OR COMMENTS \\
\hline & & $\begin{array}{l}\text { Uncertain context. A cave was researched } \\
\text { in 1964-69. A Roman altar was men- } \\
\text { tioned by the publishers. No further ex- } \\
\text { aminations were made. PINTILIE 1999- } \\
2000 \text { n. 30, 235-236. }\end{array}$ \\
\hline
\end{tabular}

\section{AMPELUM}

\begin{tabular}{|c|c|c|c|}
\hline CIMRM & $\begin{array}{l}\text { CARBÓ-GARCIA } \\
\text { (n. } 31)\end{array}$ & SICOE (n. 32) & NEW FINDS OR COMMENTS \\
\hline & & & $\begin{array}{l}\text { Seven small glazed pottery fragments } \\
\text { with possibly Mithraic iconography. } \\
\text { ANGHEL, D. - OTA, R. - BOUNEGRU, G. - } \\
\text { LASCU, I.: Coroplastica, medalioane şi } \\
\text { tipare ceramice din colecţiile Muzeului } \\
\text { National al Unirii Alba Iulia. Alba Iulia } \\
2011,57 \text {. }\end{array}$ \\
\hline
\end{tabular}

\section{UNKNOWN PROVENIENCE ${ }^{51}$}

\begin{tabular}{|c|c|c|c|}
\hline CIMRM & $\begin{array}{c}\text { CARBÓ-GARCIA } \\
\text { (n. 31) }\end{array}$ & SICOE (n. 32) & NEW FINDS OR COMMENTS \\
\hline 2180 & & & $\begin{array}{l}\text { After TUDOR, D.: Monuments de pierre } \\
\text { de la collection César Bolliac au Musée }\end{array}$ \\
\hline
\end{tabular}

${ }^{51}$ Most of the finds are listed by Vermaseren as discovered in Transylvania or Oltenia, based on the verbal confirmation of his helpers from Romania and the current place of preservation of the objects. 


\begin{tabular}{|l|l|l|}
\hline & & $\begin{array}{l}\text { National des Antichités de Bucuresti. } \\
\text { Dacia-Revue d'archéologie et d'his- } \\
\text { toire ancienne 9-10 (1945) 407-425, } \\
\text { fig. 13, the monument was found in O1- } \\
\text { tenia, although the Bolliac collection has } \\
\text { numerous finds from Dobrudja too. }\end{array}$ \\
\hline 2181 & & $\begin{array}{l}\text { After TuDOR, D.: Monuments de pierre } \\
\text { de la collection César Bolliac au Musée } \\
\text { National des Antichités de Bucuresti. } \\
\text { Dacia - Revue d'archéologie et d'his- } \\
\text { toire ancienne 9-10 (1945) 407-425, } \\
\text { fig. 13, the monument was found in O1- } \\
\text { tenia, although the Bolliac collection has } \\
\text { numerous finds from Dobrudja too. }\end{array}$ \\
\hline 2187 & & Cat. no. 219. abb. 108. \\
\hline 2190 & Cat. no. 221. abb. 142. & $\begin{array}{l}\text { Fragment of a Mithraic relief represent- } \\
\text { ing the ascension of Mithras on the } \\
\text { quadrigua. Lost. Attested in the manu- } \\
\text { script of Lugosi Fodor András. NEME- } \\
\text { TI, I.: Votive Monuments from Dacia } \\
\text { Superior in Lugosi Fodor András' Manu- } \\
\text { script. In NEMETI, S. - SZABÓ, Cs. - } \\
\text { BoDA, I. (ed.): Si deus si dea (n. 16) } \\
\text { 123. pl. I. }\end{array}$ \\
\hline &
\end{tabular}

\section{CONCLUSIONS}

From the above-presented new list of Mithraic finds from Roman Dacia, produced between 106 and $271 \mathrm{AD}$ it is possible to draw some general and specific patterns regarding the religious communication within these small religious groups. Currently, there are four Mithraic sanctuaries excavated in Roman Dacia (Slăveni, Decea Mureșului, Sarmizegetusa, Apulum), one attested epigraphically (Micia) and 15 presumed, based on the archaeological material (fig. 7). Most of the sanctuaries seems to be small or middle sized architectural entities, hosting less than 20 or even 10 persons. The total number of worshippers attested in the province represents a minor number of the Roman society from Dacia, but it is significant in comparison with other Danubian provinces. ${ }^{52}$ As was already noticed by F. Cumont, this amount of archaeological data (282 monuments, including 23 uncertain pieces) is one of the most significant in the entire Roman Empire, especially if we take into account the short existence of the province (less than 4 generations: 160 years).

More than half of the archaeological corpus and the number of worshipers are from the two urban settlements, Sarmizegetusa and Apulum, reflecting the economic,

${ }^{52}$ Clauss, M.: Cultures Mithrae. Die Anhängelschaft des Mithraskultes. Stuttgart 1992, 191-208. His list - although it is the last comprehensive one of the worshippers from Dacia - is not accurate and since than several new incriptions were found. 


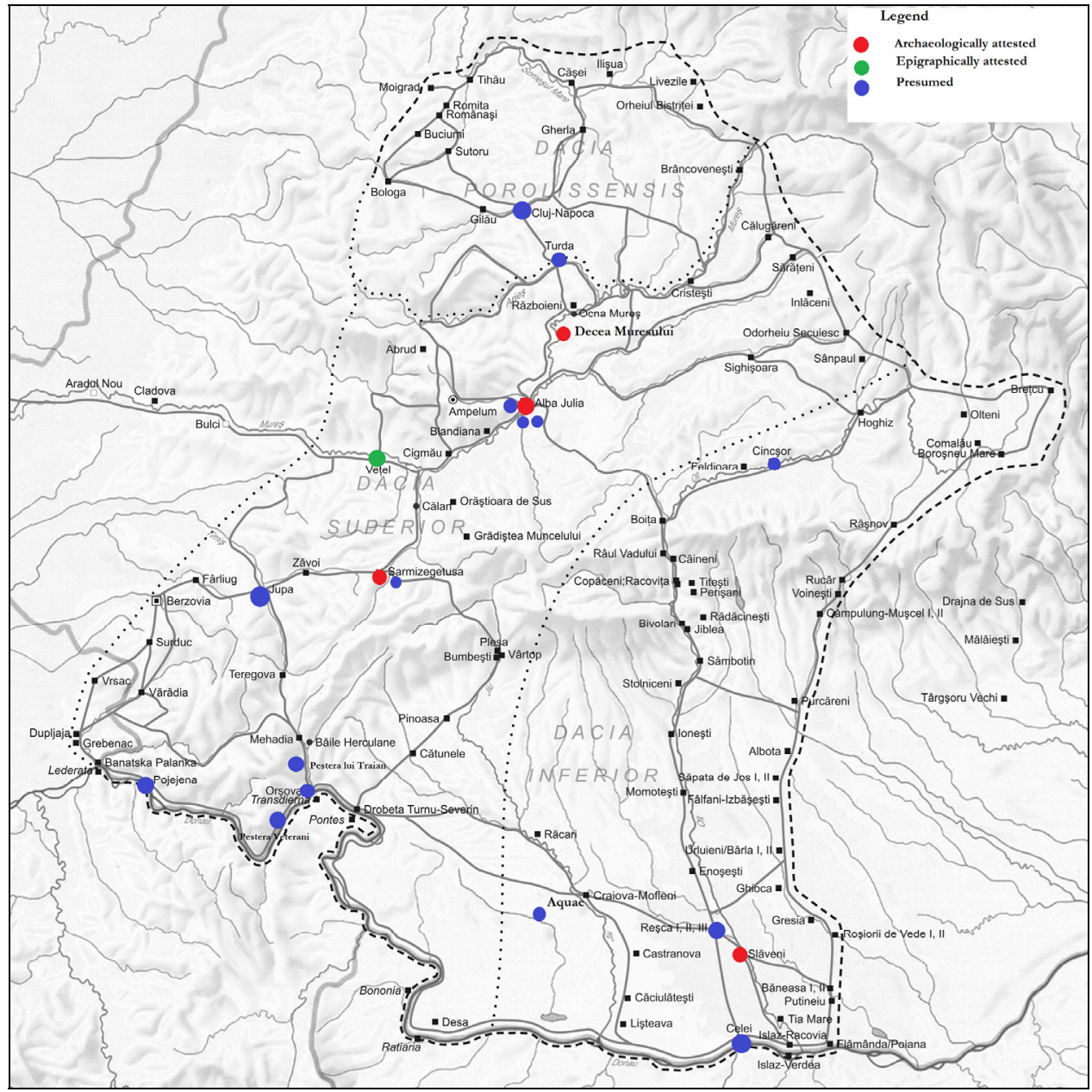

Fig. 7. Mithraic sanctuaries of Roman Dacia (map modified after SCHÄFER, A.: Tempel und Kult in Sarmizegetusa. Eine Untersuchung zur Formierung religiöser Gemeinscgaften in der metropolis Dakiens. Berlin 2007)

religious and cultural dominance of these towns in Dacia. This percentage, however, is documented not only in the case of the Roman cult of Mithras, but for the entire Roman religious materials from Dacia. The two cities produced more than half of the total number of votive inscriptions and stone monuments. ${ }^{53}$ In both cases, the majority of the worshippers are civilians, which contests the once stressed, military, aspect

${ }^{53}$ See SzABÓ, Cs.: Sanctuaries in Roman Dacia. Materiality and Religious Experience [Archaeopress Roman Archaeology Series 49]. Oxford 2018. 
of the cult. ${ }^{54}$ In many cases of documents from the land, however, the Mithraic groups were probably founded and maintained by military units. The dominance of Sarmizegetusa as the centre of diffusion of iconographies in the province seems to be a plausible assumption, ${ }^{55}$ although in numerous cases we can notice some personalized or local iconographic narratives and appropriations, featured according to individual choices, to the available materials, and to the economic possibilities. The formation, maintainance, and dynamics of Mithraic groups on local or provincial scale is very hard to reconstruct, but the available sources seem to prove the existence of an economic elite (the staff of the Publicum Portorium Illyrici and their environment) who played the key role in the organisation and maintainance of these groups. In many cases, we can attest to a dynamic mobility between sanctuaries and even cities. Some of the iconographic features - such as the representation of Cautes with bucranium, i.e., the small, portable round reliefs or the Sol with seven rays pointing toward Mithras Tauroctonos - suggest an intraconnectivity with other groups all around the Roman Empire, especially through the major commercial roads of the Publicum Portorium Illyrici (Rome-Aquleia-Poetovio-Sarmizegetusa-Apulum) and beyond (Moesiae, Thracia, Britannia, Germania and possibly even the Eastern provinces). A close relationship with the cult of the so-called Danubian Rider in Dacia was also attested. Although we do not know the exact role of the religious functions of some prominent members of these groups, some of them have a remarkable mobility in the Empire. There are very few traces of the seven grades or the internal structure of the Mithraic groups, which can be hardly reconstucted on the basis of the epigraphic material. Very few objects from the large amount of archaeological material can help us to reconstruct the religious and cognitive experiences within the sanctuaries. From the four sanctuaries excavated, only the last one, the mithraeum from Apulum, could provide us with such details.

Dacia was associated with the Mithraic finds from Transylvania already in the 18th century. Many of the first scholars dealing with the Roman cult of Mithras personally visited this part of Europe because of the large amount of Mithraic finds. The success of this cult is hard to describe, but it seems to be a quite complex phenomenon, which cannot be explained only by the presence of the Roman army, but the intraconnectivity of Mithraic groups and individuals within the province and beyond the limits of Dacia.

Csaba Szabó

Department of History, Cultural Heritage

and Protestant Theology

Lucian Blaga University

Sibiu

Romania

\footnotetext{
${ }^{54}$ See also Gordon, R. L.: The Roman Army and the Cult of Mithras: A Critical View. In LE BOHEC, Y. - WOLFF, CH. (eds): L'armée romaine et la religion. Paris 2009, 379-450.

${ }^{55} \operatorname{SICOE}$ (n. 32) 59-70.
} 
